\title{
MALIYY TEORISINDE KLASIKTEN NEOKLASIĞE GEÇiŞ: YÖNETIMSELLIK PERSPEKTIFINDEN BIR ANALIZ
}

\author{
Doç. Dr. Geyhun Gürkan \\ Ankara Üniversitesi \\ Siyasal Bilgiler Fakültesi \\ ORCID: 0000-0002-8048-7175
}

\section{Öz}

Bu çalışma Michel Foucault'nun yönetimsellik analizine başvurarak, 18. yüzyıl klasik politik iktisadın ve Ricardo sonrası iktisatta gelişim gösteren neoklasik aklın maliye teorisini liberalizmin dönüşümü bağlamında ele almaktadır. Genel yaklaşım klasik ve neoklasik ayrımını 19. yüzyılın son çeyreğine yerleştirirken, Keynes'in Ricardo sonrası iktisadı 'klasik' olarak niteleyip kendi teorisini ayrıştırması maliye teorisinde klasik-neoklasik ayrımının muğlaklaşmasına neden olmaktadır. Keynes'in tanımladığı bu ayrımın anlamının belirginleştirilmesi liberalizmin yönetim mantığı, etik felsefesi ve siyaseti üzerinden sağlanabilir. 18. yüzyıldan itibaren dönüşen liberal yönetimsel aklın ve sorunsallarının en somut hali kamu maliyesi üzerinden gözlemlendiğinden ötürü maliye teorisinin klasikten neoklasiğe, oradan Keynes'e ve devamında neoliberalizme geçişinin bu analiz ışığında değerlendirilmesi mümkündür. Foucault'nun yönetimsellik tarihi ve analitiği kamu maliyesinin tarihini ve teorisini farklı bir perspektifle ele alabileceğimiz bir çerçeve, yöntem ve araçlar seti sunmaktadır.

Anahtar Sözcükler: Klasik politik iktisat, Neoklasik iktisat, (Neo)liberalizm, Maliye teorisi, Yönetimsellik

Transition from Classical to Neoclassical in Fiscal Theory: An Analysis from Governmentality Perspective

\begin{abstract}
Drawing on Michel Foucault's analytics of governmentality, this paper addresses the fiscal theory of the classical political economy of the 18th century and that of the post-Ricardian economics in which the neoclassical mindset developed in the context of the transformation of liberalism. While the general approach places the classical and neoclassical distinction in the last quarter of the 19th century, Keynes's classification of the post-Ricardo economics as 'classical' to distinguish his theory makes the classical-neoclassical distinction in fiscal theory ambiguous. Clarification of the meaning of this distinction defined by Keynes can be achieved through the logic of liberal government as well as its ethical philosophy and politics. Since the most concrete form of the liberal governmental reason and problematics, which have been transformed since the 18th century, is observed through public finances, it is possible to evaluate the transition of the fiscal theory from classical to neoclassical, from there to Keynes and then to neoliberalism in light of this sort of analysis. Foucault's history and analytics of governmentality provide a framework, method, and set of tools through which we can engage with the history and theory of public finance from a different perspective.

Keywords: Classical political economy, Neoclassical economics, (Neo)liberalism, Fiscal theory, Governmentality
\end{abstract}

* Makale geliş tarihi: 18.06.2019

Makale kabul tarihi: 09.03.2020

Erken görünüm tarihi: 16.03.2020 


\section{Maliye Teorisinde Klasikten Neoklasiğe Geçiş: Yönetimsellik Perspektifinden Bir Analiz}

\section{Giriş}

Devlet, ekonomi ve toplum tarihinde modern kamu maliyesi düşüncesi

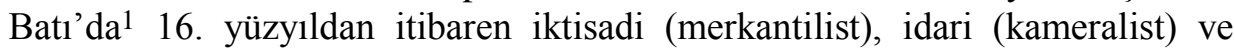
siyasal teorinin (ör. Bodin, Hobbes, Rousseau) bir parçası olarak gelişim göstermiştir. 18. yüzyılın ikinci yarısında klasik politik ekonominin içinde bağımsız bir disiplin olarak gelişiminin tohumlarının atıldığı kamu maliyesinin ayrı bir bilimsel çalışma alanı olarak kabulü iktisadi düşüncede marjinalist dönüşümün izinde özellikle 1880 'lerden itibaren gerçekleşmiştir. 1850 sonrası sosyal bilimlerin farklı disiplinler ekseninde ayrışmasına paralel olarak devletin hukuki, örgütsel ve iktisadi yapısını ve faaliyetini bağımsız ve yeni bir disiplin konusu olarak inceleyen kamu maliyesine günümüze dek esas ve egemen kuramsal çerçevesini veren neoklasik iktisat teorisi olmuştur. Kameralizm sonrası yeni devlet biçimine koşut olarak, yine organik devlet ve toplum teorisine bağlı gelişen Alman maliye düşüncesi ise neoklasik maliyenin karşı kutbunu temsil etmiştir. 1930 sonrası gelişen yeni liberal teorinin bir kolu olan Alman ordoliberalizmi de devletin piyasayı düzenleme tarzına bağlı olarak neoklasik iktisada daha fazla bağlı kalmış diğer neoliberal yaklaşımlardan ve teorilerden farklılığını sürdürmüştür. Ne var ki, günümüzde Almanya'nın iktisadi ve mali düşüncesi neoklasik iktisadın ve kamu tercihi teorisinin egemenliği altındadır (Frey vd., 2009). Dolayısıyla, 19. yüzyılın son çeyreğinde iktisadi düşüncede yaşanan devrimsel dönüşümden çıkan ve bağımsız bir disiplin olarak gelişim gösteren kamu maliyesi o günden bugüne neoklasik teorinin ve bu teorinin genel

1 İktidar ve yönetimsellik analitiğini takip ettiğimiz Michel Foucault'nun bir söyleşisinde 'Batı'dan ne anladığına yönelik sorulan soruya verdiği cevap aynı şekilde bu bağlamda akılda tutulmalıdır: "Batı dediğimde, biliyorsunuz, bu muğlak bir sözcük, kullanılması pek hoş değil ama neredeyse kaçınılmaz. Demek istediğim, Vistül Irmağı ile Ceberitarık Boğazı arasında, İskoçya'nın kuzey kıyıları ile İtalya'nın burnu arasında yer alan bir tür coğrafi bölgede, birçok şey, çok sayıda toplumsal pratik, siyasi pratik, iktisadi pratik, son derece güçlü bir şekilde doğup gelişmiştir . . .[M]odern insan olarak yazgımız . . . ortaçă̆ başı ile on sekizinci ya da on dokuzuncu yüzyıl arasında yer alan belli bir dönem boyunca bu bölgede oluşmuştur” (Foucault, 2019c: 153). 
olarak liberal teoride ve iktisadi politika alanında yarattığı dönüşümlerle ilişkilidir. Özellikle kamu kaynağı olarak (kamu girişimciliğini ve borçlanmasını bir kenara bırakarak) verginin teorisi, kamu malı sorunu, dışsallıklar ve devamında refah ekonomisi ekseninde gelişen neoklasik teori 1929 krizi ile konu alanına maliye politikasına istisnai bir gelişim olanağı tanıyan makroekonomik istikrarsızlıkları dahil etmiştir. John M. Keynes'in bu konudaki öncü rolü maliye disiplini açısından adeta 1870 'lerin iktisadi düşüncede yaşanan marjinalist devrimle eşdeğerdir. Bu bakımdan genel kamu maliyesi yazınında Keynes modern maliye biliminin kurucusu sayılmaktadir.

Keynes'in 1970'lere kadar süren fordist-kapitalist modele ulusal ve uluslararası ölçekte sunduğu iktisadi politika ve yönetim modeli yalnızca farklı türleriyle 1930'lardan itibaren gelişen bugün neoliberalizm olarak adlandırılan yeni liberal yaklaşımların ortak karşıt kutbunu oluşturmuyordu. Aynı zamanda anaakım maliye teorisinde yine iki kutbu temsil eden James Buchanan ve Richard Musgrave tarafindan Keynes'in yarattığı dönüşümün eskiye, yani neoklasik iktisadın üzerine çektiği perde farklı yönlerden sorunsallaştırılmıştır. Buchanan 1940'ların sonundan itibaren Keynes'in iktisadından doğan planlamacı ve güdümcü maliye politikası anlayışını ve genel olarak liberal teorisini aşmanın yolunu ararken öncesindeki Kıta Avrupası maliye geleneğinin İsveç ve İtalyan ekollerinden çıkış almıştır. Musgrave de farklı bir yönden Keynes'in yarattı̆̆ devrimi maliyenin bağımsız bir disiplin olarak gelişimi önünde yarattığı bir sorun olarak görmüş olsa gerek ki Keynes öncesi maliye düşünce tarihinin üzerine eğilerek 1958'de Alan T. Peacock ile derlediği Classics in the Theory of Public Finance (Maliye Teorisinde Klasikler) adlı kitapta İtalyan, Fransız, İsveç, Avusturya ve Alman maliye teorilerini İngilizce konuşulan dünyaya taşımıştır. Musgrave ve Peacock derlemeye yazdıkları giriş bölümünün ilk cümlesinde 1929 buhranı sonrasında maliye teorisinin derlemede klasik yazıların temsil ettiği problemden ve odak noktasından uzaklaşıp farklı bir konu alanına yerleştiğini belirtmektedirler. Buna göre, maliye teorisinde "kaynakların ne zaman ve nerede özel kullanımdan ziyade kamuya ayrılacağ 1 ve maliyeti kimin üstleneceği klasik sorusu"ndan "gelir, istihdam ve fiyat düzeylerine maliye politikasının etkilerinin araştırılması"na (Musgrave ve Peacock, 1964: ix) geçilmiştir. Kitap bu önceki (neo)klasik soruyu tekrar maliye teorisinin gündemine ve merkezine alınması için hazırlanmıştı ve bir nevi Keynezyen devrimin izinde maliye teorisinin merkezine makroekonomik istikrarsızlıkların ve maliye politikasının yerleşmesine bir liberal tepkiyi temsil etmekteydi. Belirtildiği üzere, genel kamu maliyesi yazınında Keynes'in kitabı Istihdamın, Faizin ve Paranın Genel Teorisi (The General Theory of Employment, Interest and Money) modern maliye biliminin doğuşu olarak konumlandırılır. Bunun nedeni Keynes'in yatırımların düştüğü ve bunun sonucu olarak tasarrufların azaldığı, işsizliliğin yükseldiği, ücret ve fiyat deflasyonunun güçlü bir zemin kazandı̆̆ 1 , sermayenin kârlılık 
krizinin yaşandığı ve ekonominin uzun süreli böyle bir bunalım ortamında takılı kalma eğilimi gösterdiği bir ortamda toplam talebin bileşenlerine (yani öncelikle kapitalistlerin yatırım ve ücretli kesimin tüketim taleplerine) yönelik maliye ve para politikası ile aktif devlet müdahaleciliğinin gerekliliğini savunmuş ve bunu kuramsallaştırmış olmasaydı (Backhouse, 2008: 29). Musgrave (1959) de Keynes'in iktisat teorisinde ve politikasında yarattığı bu 'devrimci' dönüşümü modern neoklasik maliye teorisine taşıyarak kamu maliyesine kaynak dağılımı, gelir dağılımı (bölüşüm) ve istikrar adı altında üç işlev ve görev biçmiştir (ayrıca bkz. Kurz, 2017: 170-171). Ne var ki David Laidler'in belirttiği gibi Keynes'in kitabı yatırımların belirlediği gelirin bir fonksiyonu olan ücreti ve ücretli kesimin talebini merkeze alan maliye teorisi veya politikası üzerine değildi; öyle olsaydı kitabının başlığı İstihdam, Faiz ve Paranın Genel Teorisi değil de örneğin İstihdam, Ücretler ve Maliye Politikası olurdu. Kitap piyasa ekonomisi içinde paranın rolü ve istihdamın tam istihdam düzeyinin altına inmesinde rol oynayan faiz oranı üzerineydi (Laidler, 2008: 46-47). Ancak Keynes'in iktisat teorisi tüketicileri kahraman haline getiren ve efektif talep yönetimini gözeten maliye politikasına indirgenerek kapsamı daraltılıp anlaşılmaması gerekse de, 'Keynesçi Devrim' nitelendirmesini haklı kılan unsurun Keynes' in maliye politikasına alan açan makroekonomik politika yönünde yarattığı köklü değişim olduğunu söylemek yanlış değildir.

Keynes açısından konunun iki yönü söz konusuydu: Aktif devlet müdahaleciliğini ideolojik olarak savunması yeni bir liberal felsefe içinde şekillenmişti; ayrıca kuramı 'klasikler' olarak adlandırdığı iktisat teorisine karşı çıkışın sonucuydu. Keynes'e zamanında ve sonrasındaki itirazlar da liberalizmin içinde devleti konumlandırma ve yeni bir liberal toplum ve yönetim felsefesi geliștirmesine; ayrıca 'klasikler' in arz yönlü yaklaşımının yerini toplulaştırılmış efektif talep yönetiminin alacağı şekilde ekonominin ücret, fiyat, faiz ve yatırım arasındaki kuramsal ilişkilendirmesine yönelik gelişmişti. İktisat teorisi ve ideolojisi neoklasiklerin indirgemeciliğinden ve öznelciliğinden çıkıp Keynes ile yapısal bir özellik kazanıyordu (Wolff ve Resnick, 2016) ve Keynes sonrası neoliberal iktisadın ve maliyenin temel itirazı buydu. İktisat/maliye teorisinde/politikasında bireycilikten/öznelcilikten yapısalcıllğa doğru bu köklü dönüşümü Keynes 'klasik' ve 'klasikler' adını verdiği iktisat teorisine ve iktisatçılara karşı gerçekleştirdiğini yazmaktaydı. Peki Genel Teori'nin teorik eleştirisinin ve dönüştürdüğü klasik liberal ideolojinin muhatabı kimlerdi? Keynes kitabının hemen başında "klasik teori”'den (Keynes, 1964: 3) anlaşılması gerekeni dipnotta açıklamaktadır:

'Klasik iktisatçılar' Ricardo ve James Mill ve onların seleflerini kapsayan, yani Ricardo iktisadında doruğa çıkmış teorinin kurucuları için, Marx tarafından icat edilmiş bir isimdi. Ben, belki kural dışı davranarak (solecism), 'klasik okula' Ricardo'nun takipçilerini, yani (örneğin) J. S. 
Mill, Marshall, Edgeworth ve Prof. Pigou gibi Ricardocu iktisat teorisini benimseyenleri ve mükemmelleştirenleri dâhil etmeyi alışkanlık edindim (Keynes, 1964: 3n).

Keynes aslında basit bir isim değiştirmeye gitmemiştir. Şüphesiz klasik (1750-1870) ve erken neoklasik ekol (1870-1930) olarak iktisadi düşüncede genel kabul görmüş ayrımın farkındaydı ve sözlerine bakıldığında Ricardo ve sonraki iktisat arasında tam bir süreklilik görmekteydi ve bu süreklilik onun için laissez-faire iktisadını ve ideolojisini tanımlamaktaydı. Örneğin Kasım 1924’te verdiği bir derste Ricardo öncesi 18. yüzyıl iktisadında genel çıkar ile özel çıkarın her zaman uyuşmadığını, bunun böyle bilinmesinin nedeninin konuyu basitleştiren ve vulgarize eden sonraki laisssez-faire iktisatçılarının olduğunu söylemekteydi (Keynes, 1924a; Vergara, 2006: 189). Ricardo ve ondan daha fazla John S. Mill ile neoklasik iktisat arasındaki süreklilik liberal ideoloji ve felsefe bakımından ne denli yakın görülse de, 18. yüzyıl politik iktisatçıları (Hume, Ferguson, Steuart ve Smith) ile J. S. Mill'in iktisadı arasındaki dönemi klasik politik iktisat olarak adlandırmayı kamu maliyesi perspektifi açısından haklı çıkaran noktalar vardır. Marx'ın klasik politik iktisattan anladığı düşünce ekolü, kendi sözleriyle, "W. Petty'den bu yana, burjuva üretim ilişkilerinin iç bağlantılarını araştırmış bütün iktisat" (Marx, 2012: 36n) idi. Marx özelinde bunun dışında kalan 'bayağı iktisadın' içinde örneğin Say'nin ve Bastiat'nın olduğu kesinse de, Ricardo sonrası politik iktisadın ismi Mill'in yer alıp alamayacağı bir tartışma konusudur; ancak 1870 'de C. Menger, L. Walras ve S. Jevons'un gerçekleştirdiği dönüşümün (ya da devrimin) iktisadi düşüncede radikal bir ayrıma oturduğu genel olarak kabul edilir. Keynes Ricardo sonrası iktisadı bir bütün olarak bayağı (vulgar) görüp reddetmemiştir. İstisnaların içinde Alfred Marshall gibi bir neoklasik iktisatçı da vardır. Marshall'ın ölümü üzerine 1924 'te yazdığ 1 metinde Marshall'a göndermede bulunarak çağdaş (neoklasik) iktisat teorisinden ve iktisatçıdan ne anladığını şu şekilde dile getirmişti:

İktisat biliminin sıra dişı bir yüksek seviyenin ihtisasa dayanan nimetlerinden hiçbirine ihtiyacı yokmuş gibi bir görünümü söz konusudur. Entelektüel açıdan, felsefenin ve soyut bilimin daha yüksek kollarıyla karşılaştırıldığında iktisat bilimi çok basit kaçmıyor mu? Şimdi iyi, hatta ya da işin ehli benzersiz iktisatçılar az sayıdadır. . . [i]]ktisatçının erbabında az rastlanan bir hüner karışımı olmalıdır. Usta bir iktisatçı farklı birçok alanda yüksek standartlara ulaşmış ve bir araya gelmesi nadir görülen hünerlere sahip olmalıdır. Belli ölçüde bir matematikçi, tarihçi, devlet adamı, felsefeci olabilmelidir. Sembolleri anlamalı ve fakat kelimelerle konuşabilmelidir. Tekili genele dayanarak düşünebilmeli ve aynı düşünce akışı içinde soyut ve somut olana temas edebilmelidir. Şimdiyi geçmişin 1şığında, gelecekteki amaçlar için incelemelidir. İnsanın doğasının ve kurumlarının hiçbir yönüne tamamen kayıtsız kalmamalıdır. Mesafeli ve 
dürüst bir sanatçı gibi ama bir politikacı kadar da dünyaya yakın kalarak aynı anda kararlı ve önyargısız olabilmelidir (Keynes, 1924b: 321-322).

Keynes'in (neoklasik) iktisat biliminden ve iktisatçıdan ne anladığını gösteren bu satırlar 'klasikler' adını verdiği Ricardo sonrası iktisadın realizmden uzaklaşarak içine düştügü durumu betimlemektedir ve Keynes için iktisadi düşüncedeki ayrımın neye temellendiğini de tanımlamaktadır. Ricardo öncesi iktisattan ilham alınacak noktaları gösteren satırlar olarak da bunlar okunabilir.

Dolayısıyla, Keynes iktisadi düşünce tarihini Ricardo öncesi, sonrası ve kendisinden sonraki dönem olarak ayırmışıtır. Genel olarak kamu maliyesi ve maliye teorisi açısından bakıldığında bu ayrım modern maliye biliminin kurucusu olarak Keynes görüldüğünde yaygın bir kabule denk düşmektedir. Ancak iktisadi düşünce tarihinde genel kabul görmüş ayrıma ve adlandırmaya göre 1870’lerdeki klasikten neoklasiğe geçiş biçimindeki süreç kendi içinde bir tartışmaya sahiptir ve Keynes'in Ricardo ve kendisi üzerinden tanımladığı ayrım bu tarihe denk gelen geçişi ve tartışmaları muğlaklaştırmaktadır. Bu dönüşümün bir devrim mi yoksa bir süreç içinde süreklilik mi olduğu iktisadi düşünce tarihçileri arasında devam eden bir tartışma konusudur. Aynı şekilde ister devrimsel bir dönüşüm ister adımsal yenilikler içinde süreklilik söz konusu olsun değişimin ya da dönüşümün unsurları da tartışma konusudur. Neoklasik iktisadın temeli olarak görülen marjinalizmin (iktisadi olayları marjda/sınırda kavrama) Ricardo'nun farklılık rantı teorisinde, hatta onun öncesinde, gözlemlenebilir olduğu (Myrdal, 1953: 75) ve homo economicus temel varsayımı ve indirgemeciliği ile iktisadın yapısal bir teorik düzlemden bilişsel/zihinsel ve psikolojik bir içerikle insan eylemi teorisine yönelmesinin J. S. Mill'in politik iktisat teorisinde zemin kazandığ 1 düşünüldüğünde (Schabas, 2005), Keynes'in ayrımını kamu harcamalarını konu dışı bırakan ya da olabilecek en yüksek şekliyle sınırlamayı gözeten Ricardo iktisadı ve sonrasına dayandırması kökleri eskiye giden bir neoklasik ekol kavramsallaştırması açısından anlamlı olabilir. Diğer taraftan, iktisadi düşünce tarihçisi Heinz D. Kurz konuya ilişkin şunu belirtmektedir: 'Keynes' in kendisi 'klasik teori' den söz etti ama gerçekte demek istediği neoklasiktir. Genelde iktisadi düşünce tarihi ile ilgili kesin bir bilgiye sahip olmamıștır" (Kurz, 2017: 161). Kurz'un iddiası ile birlikte değerlendirildiğinde Keynes'in klasikleri tanımlama biçimi kendisinin de kabul ettiği gibi kişisel tercihe bağlı bir hata ya da genel duruma aykırı bir davranış (solecism) olarak görülebilir, ya da neoklasik dönüşümün Ricardocu köklerine vurgu yaparak adımsal bir dönüşüme ikna olduğu düşünülebilir. İkincisi de Keynes'e uygun gibi durmaktadır. Kesin olan nokta ise Kurz'un belirttiği gibi Keynes'in daha çok muhatap olarak neoklasikleri, özellikle neoklasik fikirleri geliştiren iktisadın ortodoks kanadını kastettiğidir. Bir diğer kesin nokta Ricardo öncesinin klasik politik iktisada ve klasik liberalizme, sonrasının neoklasik 
iktisada ve ona uygun farklı türden bir liberalizme tekabül ettiğidir. Klasik liberalizm ile Ricardo'dan başlayan ve neoklasik iktisada evrilen laissez-faire ideolojisi ve liberalizmi arasında bir ayrım yapılırsa buradan çıkan ilginç bir sonuç neoliberalizm ile Ricardocu iktisat ve neoklasik iktisat arasındaki farklılaşan derin bağlardır ve neoliberalizm ile Adam Smith'in temsilcisi olduğu klasik liberalizm arasındaki derin uçurumdur aynı zamanda. Dolayısıyla tartışma iktisadi varsayımlardan bir yönetim felsefesi, bilgisi ve siyaseti olan liberalizme taşındığında ayrımlar ve süreklilikler farklı bir perspektiften belirginleştirilebilmektedir.

Keynes'in maliye politikası ile maliye teorisinde gerçekleştirdiği devrimsel dönüşüm kendisi için ayrıca liberalizmden ne anladığı sorusuna dönüşmüş ve bu Keynezyen düşünce açısından hâkim kapitalist düzenin tanımlaması olan neoliberalizm karşısında her zamankinden daha fazla önem kazanmıştır. Keynezyen iktisadın yanında Keynezyen liberalizmin neoklasik iktisadın ve ona uygun liberalizmin düşünsel ve politik yapısından beslenen neoliberalizm karşısında çağın gereklerine uygun muhalif bir iktisat-maliye teorisi/politikası ve liberal ideoloji sunabilmesi için Keynes'in kendinden önce Ricardo'dan başladığını söylediği 'klasik' olarak tanımladığı düşünsel okulun gerçek klasik çağ olan 18. yüzyıl ile farkını bu açıdan belirginleştirmek gerekir. Dolayısıyla, yalnızca iktisadi düşüncede alışılagelmiş 1870 öncesi ve sonrası klasik-neoklasik ayrımına göre değil, Keynes' in tercihine bağlı olarak ancak isim ve perspektif değiştirerek Ricardo öncesi ve sonrası dönem ayrımını da dikkate almak gerekir. Bu yaklaşım ve ayrım genel kabul görmüş 19. yüzyılın son çeyreğine denk gelen klasik-neoklasik iktisat düşüncesinin ayrımlarını da maliye disiplini açısından daha belirgin kılabilecektir ve Keynes'in hem liberalizmden anladığı düşünceye bağlı olarak hem de bu konuda kendi özgünlüğünü ön plana getirmek için yaptığı ayrımın maliye teorisi açısından yarattığı muğlaklığı da giderebilmektedir.

Bu bağlamda, Keynes'in tercihini, yani Ricardo öncesi ve sonrası ayrımını kendi neoliberal gündemimize değin süren ontolojik ve epistemolojik içerimlerini sergileyebilmek amaciyla farklı bir düzlemde değerlendireceğiz. $\mathrm{Bu}$ düzlem uzun tarihsel dönemler arasında süreklilikleri ve süreksizlikleri gözlemleyen tarihçi ve felsefeci Michel Foucault'nun (2013; 2015) yönetimsellik perspektifi ve analitiğidir. Bu perspektif ve analitik bize Keynes'in tarif ettiği ayrımın liberal-neoliberal ayrım olarak nasıl yeniden kurgulanabileceğini göstermektedir. Başka bir yönden, köklerini (Keynes'e göre klasik) neoklasik iktisattan alan neoliberalizmi klasik liberalizmden (Keynes'e göre Ricardo öncesi) ayırarak bugünün içinden eleştirel bir liberal ve iktisat teorisinin mümkünlüğü tartışmaya açılabilmektedir. Kısacası, bu analiz düzeyi 18. yüzyıl klasik politik iktisadının maliye teorisini ve Ricardo sonrası gelişim gösteren neoklasik aklın maliye teorisini liberalizmin dönüşümü bağlamında ele 
almaktadır. Kapitalist ekonomi teorisinin genel yöntemi ve ilkeleri klasik ve neoklasik ayrımını 19. yüzyılın son çeyreğine yerleştirirken, Keynes'in ayrımının anlamının belirginleştirilmesi ancak liberalizmin yönetim mantı̆̆ı, etik felsefesi ve siyaseti üzerinden sağlanabilir. Keynes'in de bu ayrımı yalnızca kapitalist piyasa ekonomisinin işleyişini gösteren genel iktisadi teorik ilkelere referansla yapmadığını, aynı zamanda Ricardo sonrası liberal yönetimsel düşünümdeki belirgin bir dönüşümün olduğu fikrine bağlı olarak hareket ettiğini rahatlıkla düşünebiliriz. Keynes'in kendini liberalizm üzerinden ifade etmeye çalışmasına bakıldığında bu doğru bir analiz düzlemidir. Liberalizmin 18. yüzyıldan itibaren dönüşen yönetimsel aklı ve sorunsalları en somut hallerini kamu maliyesi üzerinden sunduğu için maliye teorisinin klasikten neoklasiğe oradan Keynes'e ve devamında neoliberalizme geçişini de bu analiz boyutunda değerlendirebileceğiz.

\section{Klasik Politik İktisattan Neoklasik İktisada Maliye Teorisinde Dönüşüm}

Yukarıdaki düşüncelerin izinde maliye teorisinde klasikler (Ricardo sonrası) ve Keynes arasındaki ayrımı genel iktisadi düşünce tarihi algısına bağlı kalarak Keynes öncesi dönem içinde klasik ve neoklasik olarak kurguladığımızda 1750-1870 ve 1870-1930 gibi kendi içlerinde tutarlı iki dönem belirmektedir. 1820 sonrası Ricardo iktisadının hâkimiyeti altında gelişen dönem yine genel algıya ve kabule göre klasik politik iktisat olarak nitelenebilirse de neoklasik aklın geliş̧iminin farklı yönlerden izlenebildiği bir zaman aralığı olduğu rahatlıkla söylenebilir. Mutlak bir 1870 öncesi ve sonrası ayrımına bağlı olarak klasik iktisadi düşünce tarihinde maliye teorisini inceleyen Takuo Dome (2004) Britanya klasik politik iktisadı içindeki maliye teorisi tarihini David Hume'un 1752 tarihli "Vergiler Üzerine" (1970a) ve "Kamu Borcu Üzerine" (1970b) başlıklı yazılarından başlayarak inceler; ancak sistematik bir bilgi biçimi olarak gelişimini 1767-1873 arasına yerleştirmektedir. 1767 James Steuart'ın Inquiry into the Principles of Political Oeconomy (1998) kitabının, 1873 ise J. S. Mill'in ölümü ve son yazılarının yayımlandığı tarihtir. Bu tarih aynı zamanda iktisadi düşüncede marjinalist dönüşümün gerçek iktisatçıları olarak görülen C. Menger, S. Jevons ve L. Walras'ın 1871-1874 arasında peşi sıra kitaplarını yayımladığ 1 döneme denk gelmektedir. Steuart'tan Mill'e uzanan bu yüz yılı aşkın dönem içinde Britanya klasik politik ekonomisinde maliye teorisine yön veren iktisadi düşünceden biri fizyokrasi diğeri Hume'un maliye teorisi ve politik iktisadıdır. Fizyokratların tarımsal ranta tek vergi teorisi tarımın Fransa'da kapitalistleşme gerçeği ve politik savunusuyla uyumludur; ayrıca ürünün ve gelirin sinıflar arasında dağılımının nihai sonucu olarak sadece rantın vergilendirilmesi gerektiği yönündeki teorik ilke Britanya klasik politik iktisatçıları için verginin 
yansıması konusunda temel tartışmayı oluşturmuştur. Tam da ayrımı Ricardo'ya işaretleyen Keynes'i haklı çıkaracak şekilde bu konudaki devrimsel teorik dönüşümü Ricardo Ekonomi Politiğin ve Vergilendirmenin İlkeleri'nde (18171821) yapmıştır. Ekonominin kapitalistleşme derecesi arttıkça ve büyüme sağlandıkça kapalı ekonomi modelinde farklılık rantı ve tarımda sermayenin hareketliliği varsayımı ile vergilerin birçoğunun rantlar yerine kârlara düşeceğini göstererek Ricardo fizyokratlardan başlayıp Steuart'1, Smith'i ve Malthus'u etkisine alan, gerçek vergi ödeyicisinin üretken olmayan sınıf olarak toprak sahipleri olduğu yönündeki düşünceyi bertaraf etmiştir. Gelişen kapitalist ekonomide toplumun genel çıkarı ile koşulsuz olarak sermaye sınıfının özel çıkarının uyuştuğu yönündeki kurucu burjuva ideolojisi verginin yansıması teorisiyle Ricardo ile başlamaktadır.

Diğer taraftan, 18. yüzyılın liberalizminden 1873 'e uzanan bu 'klasik' çağ 1 kendi içinde tutarlı kılan esas nokta Dome’ye göre dönemin bir bütün olarak "Hume'un mirası" üzerine yükselmesidir. Bu miras Hume'un adı geçen iki kısa yazısında klasik politik iktisadın maliye teorisi alanını üç soru bakımından nasıl şekillendirdiğini tanımlamaktadır: "(1) Hükümet harcamalarının yönetimi, (2) adil ve etkin bir vergi sistemi. (3) borç yönetimi”" (Dome, 2004: 5). Klasik politik iktisatçılar bu üç konu alanında Britanya'nın mali sisteminden kaynaklanan somut problemleri göz önüne alarak maliye teorileri ve pragmatik öneriler geliştirmişlerdir. Bu bakımdan hepsi, Ricardo gibi en soyut iktisada yönelen iktisatçı dahi, gerçeklikten kopuk değillerdi ve teorilerinin varsayımları, farklılıkları ve politika dizaynına yönelen çözüm arayışları gerçeğin somut problemlerinden kaynaklanmaktaydı (Dome, 2004: 207-209). Gerçekle ilgili doğrudan bağlantıları Britanya politik iktisatçılarını kuramlarında paradokslara yönelten sonuçlara da neden olmuştur. Smith'in eşitlik arayışında tüm faydacıllğına rağmen ödeme gücü ilkesini tamamen bir kenara bırakamaması ve ticaretin zararlı toplumsal etkileri karşısında kamu harcamalarına geniş bir alan açması, Malthus'un savaş koşullarından kaynaklanan somut problemler karşısında ve Steuart'ın devlet adamının eli teorisinin bir parçası olarak özellikle ticaretin durgunluk aşamasında geçerli olan talep yönlü yaklaşımı benimsemesi, Ricardo'nun vergilere yönelik köklü itirazlarına rağmen kamu borcuna gösterdiği liberal duyarlılık ve bunun sonucu 'itfa fonu'nun (sinking fund) başarısızlı̆̆ 1 karşısında sermaye/servet vergisi savunusu, Bentham'ın reformizmi, J. S. Mill'in artan eşitsizlikler karşısında neoklasik iktisada yönelik bireyci ideolojiyi ve analitik çerçeveyi kurarken çağdaşlarının sosyalist olma suçlamasıyla karşılaşmasına varacak şekilde yeniden dağıtımcı bir devlet fikrine yaklaşması, ve de tersinden McCulloch'un yükselen sinıfsal karşıtlıklar karşısında erken zamanlarında savunduğu Ricardocu iktisadın sınıfsal içeriğini yüzyılın ikinci yarısından sonra boşa çıkarması... Tüm bunlar Steuart'tan Mill'e uzanan klasik dönemin iktisatçılarının kendi içlerindeki yöntemsel ve politik 
dönüşümlerine rağmen realizmden ayrılmadığının kimi örnekleri ve göstergeleridir.

$\mathrm{Bu}$ realist yaklaşım 1880 sonrası neoklasik maliyenin tümdengelimsel yönteme bağlı gelișen matematiksel araçlara dayanan soyut iktisadının içinde kaybolan önemli bir özelliktir. Bu gerçekçi sorunlardan kopuşun en önemli göstergelerinden biri de Ricardo'nun, Keynes'i haklı çıkaracak şekilde, bayağ 1 iktisada uygun bir şekilde kamu harcamalarını konu alanı dışına itmesi ve bunun neoklasik iktisatta minimum harcama biçiminde politik varlığını kaybederek salt vergilemede (sınıf yerine) bireyler arası eşitlik koşulunun bağımlı ya da bağımsız teknik bir parçası olarak ele alınmasıdır. İktisadın realizminde marjinalizmle beraber seviye kaybının en önemli diğer göstergelerinden biri de borç sorununun artık liberal bakışın bir parçası olarak ele alınmamış olmasıdır. Oysa kamu borcu sorunu Hume'dan itibaren demokrasinin bir sorunu olacak şekilde dahi incelikli analizlere tabi tutulmuştur. Devletin sınırlandırılması biçimindeki liberal tutumun bir parçası olarak ele alınmış olsa da, Hume'un devlet borcu ile yükselen finansörlerin çağında despotizmin bir sonuç olarak çıabileceği tespiti, Smith'in kamu borcunun azaltılması için sömürgecilikten vazgeçilip ulus-devlet modelinin sağlamlaştırılması önerisi, Steuart, Malthus ve J. S. Mill'in somut sorunlar karşısında maliye politikasının bir aracı olarak kamu borcunu talep yönetimi açısından görebilmesi ve Ricardo'nun (1997: 216-217) (neoklasik yorumunun tersine) kamu borcunun varlık illüzyonu yaratarak ekonominin gerçekçi bir işleyişten uzaklaşma eğilimi göstermesine neden olduğu yönündeki tespiti bugün neoliberal finans çağında yeniden düşünülmesi gereken ve eleştirel bir yaklaşımın odağında yararlı olabilen çözümlemelerdir. Ayrıca kapitalizmi sınıfsal bağlarıyla birlikte klasiklerin, özellikle Smith'in tarihsel, sosyolojik ve kurumsal kavrayıșı bugün kamu maliyesi teorisinin sosyolojik çıkıș arayan denemeleri için muazzam bir tarihsel ve yöntemsel kaynak sunmaktadır. Klasik politik iktisadın 'ilke'lerinden kopup neoklasiklerin soyut varsayım ve kapalı epistemolojik ve 'teorik' dünyasına yerleşen neoliberalizmin yalnızca kuramsal olarak değil devletleri, toplumları ve bireyleri yönetme tarzındaki bayağılık ve şiddet arttıkça klasikler aydınlanmanın ürünü olarak hem liberalizmin eleştirisi hem de farklı bir liberal tahayyülün gelişimi için önemini korumanın ötesinde arttırmaktadırlar.

Patrick O'Brien (1975: 265) klasiklerin maliye teorisinin neoklasiklerle karşılaştırıldığında ilkinin gerçekçi yapısının ilgiye ve dikkate değer bir düşünce çıkardığını ancak ikincisinin sofistikasyonu, analitik yapısı ve ilgilendiği konu çeşitliliği karşısında klasiklerin yetersizliğini vurgulamaktadır. Bunun en önemli nedeni maliye teorisinin politik iktisatçıların metinlerinde bir bölüm olarak yer alırken ya da Malthus'ta olduğu gibi dolaylı olarak değinilen, sistematik ve çeşitlilik gösteren bir yapı kazanmaması, Dome'nin (2004) yerinde tanımıyla Hume'un sorun alanından uzaklaşmamasıyla ilgilidir. Neoklasik maliye ise 
politik ekonominin politik kısmından uzaklaşıp (Gulbenkian Komisyonu, 2003: 24), klasiklerce esas iktisadi yöntem olarak değil de, bir liberal etik ölçüt olarak benimsenmiş faydaya odaklanarak, faydayı tümdengelimsel yöntemin matematiksel araçlarıyla iktisadın genel yöntemi haline getirmiş ve marjinalizmi kamu ekonomisine uygulayarak düşünsel bir analitik zenginlik yaratmıştır. Ancak realizmin bağıntılarından kendini soyutlayarak bunu gerçekleştirmiştir ve bu ilerlemenin 'alternatif maliyeti' ağır olmuştur. Bunun en önemli göstergelerinden biri 1. dünya savaşı sonrası yaşanan makroekonomik istikrarsızlıkların karşısında iktisat bilimi gerçek dünyayı algılamaktan uzaklaşmış ve politika geliştirme yetersizliği 1929 krizinin önemli nedenlerinden biri olmuştur. Aynı sürecin başında 1920'lerde neoklasik iktisatçılar ve maliyeciler İtalya'da krizden çıkış adına ücretleri düşürmeyi amaçlayan Mussolini'nin yönetimine kemer sıkma politikaları bağlamında teorik ilkeler ve politika araçları sunmuş (Mattei, 2017) ve neoliberalizmin 1970'lerde Şili'deki başlangıcının provasını yapmışlardır.

Neoklasik iktisadın, politik iktisadın politikasından kurtulması farklı birkaç anlama gelmektedir: Emek sorunundan ve onun siyasal içerimlerinden kurtulup hazcı ve egoist birey doğasını iktisadın analitik birimi ve öznesi haline getirerek 'ülke ekonomisi' anlamındaki politik iktisadın makroekonomik perspektifini tüketici egemenliği nosyonuyla değiştirmesi ve devlet ekonomisinin sınırlarını çizebilme arayışı olarak bunlar ifade edilebilir (Clarke, 1991: 188). Ancak İtalya'daki Mussolini faşist yönetimi ile neoklasik iktisatçıların ve maliyecilerin bağıntısı iktisattaki sorunun Smith'te olduğu gibi devlet-sivil toplum sorunu olmaktan çııı devlet-birey sorunu haline getirildiğinde iktisat biliminin nasıl bir politik sonuca varabileceğinin en açık tarihsel örneklerinden biridir ve tarihteki erken neoklasik deneyim bugün neoliberaller tarafından devralınmıştır. Bu gerçek, neoliberalizmin Keynes ile kavgasında planlamacı, güdümcü, kolektif ve toplumsal çıkara dayalı bir iktisat ve maliye anlayışının asıl olarak despotik bir politik düzene dönüşeceği yönündeki iddiasından vazgeçmemesinin en önemli nedenidir. Bunun yanlışlı̆̆ 1 ise yine teorinin 'köklerine' yani bireyi topluma içkin ve bağımlı kılmış Smith'e (2006) dönerek rahatlıkla gösterilebilir.

Neoklasik iktisat denildiğinde ne anlaşıldığı sözcüğün Veblen tarafından 1900 'de "The Preconceptions of Economic Science" adl1 yazısında icat ettiğinden beri aradan geçen yüz yirmi yıla yakın zaman diliminde hem ortak özellikleri bağlamında hem de ekollere göre farklılıklarıyla anlaşılmıştır. Örneğin E. K. Hunt ve M. Lautzenheiser (2016: 21-22) neoklasik iktisadın 19. yüzyıla uzanan tarihinde üç değişmez ilkesini şöyle tanımlamaktadır: Rasyonel piyasa fiyatlarına dayan kapitalist ekonominin sorgulanmaz akılcılığı ve etkinliği; kendi kendini düzenleyerek uyum içinde çalışan otomatik piyasa mekanizmasının varlığı; kapitalizmin bölüşümde adaletin ideal mekanizma 
olması. Veblen ise neoklasik iktisadı öncelikle klasiklerin devamı biçiminde gördüğünden bu sözcükle "modernize edilmiş klasik bakış açıları"nı (Veblen, 1900: 262) kastetmiştir. Veblen'in eleştirisinin merkezinde klasiklerden neoklasiklere uzanan iktisat düşüncesinin piyasa fetişizminin 'iş' (business) düzenini hukuksal, politik-idari, etik ve kültürel normatif düzlemlerde savunması ve iktisadı evrimci bir bilimden uzaklaştıran tarih-dışı, seküler olmayan, statik sınıflandırıcı ve ereksel teorik içeriği ve yapısı yer alır. Günümüzde ise egemen iktisat bilimi yine neoklasik iktisat olarak adlandırılırken önemli bir fark neoklasik iktisadın neoliberal ideolojiye ve siyasete göre şekillenmesidir. II. dünya savaşı sonrası fordist dönemde Keynezyen bir etki ile şekillenen neoklasik iktisat öğrenimi bugün Veblen'in eleștirdiği iș düzeninin tüm boyutlarını içeren neoliberalizmin etkisi altındadır. Neoklasik iktisat, iktisat öğretiminde ders kitapları ile egemenliğini sürdürürken neoliberalizmin değerlerini ve yaklaşımını üreten ve yayan temel yönetimsel bir araç olarak kritik bir işlevi de üstlenmektedir (Zuidhof, 2014). Al Campbell vd. (2018) Gregory Mankiw'in çok satan ders kitabını (Principles of Economics) incelemeye tuttuklar1 "Neoklasik İktisadın Gerçek Dışı Temeli" ("The Unreal Basis of Neoclassical Economics") başlıklı yazıda anaakım iktisadın 2008 krizi sonrasında indirgemeci ve basitleştirici yapısından kaynaklanan tüm gerçek dışılığını ve işlevsizliğini sürdürdüğünü belirtmektedir. Dünyayı açıklayan bilimsel bilgi yerine neoliberalizme uygun normatif bir yönetim aklı ve ilke bütünü geliştiren neoklasik iktisadın bu yeni neoliberal misyonu karşısında yazarlar Mankiw'in gerçekliği kavramaktan uzak ve gerçeği belirli bir ideolojik yönde şekillendirmeye dönük on normatif ilkesini suralayarak eleştirel bir incelemeye tutmaktadırlar: "i) İnsanlar değiş-tokuş yaparlar / bedava öğlen yemeği diye bir şey yoktur. ii) Bir şeyin maliyeti onu elde etmek için vazgeçtiğiniz şeydir / alternatif maliyet. iii) Rasyonel insanlar sınırda (margin) düşünür. iv) İnsanlar güdülere göre tepki verir. v) Ticaret herkesin refahını artırır. vi) Piyasalar genellikle ekonomik eylemi organize eden iyi bir yoldur. vii) Hükümetler bazen piyasa sonuçlarını iyileştirebilir. viii) Bir ülkenin yaşam standardı mal ve hizmet üretebilme yetkinliğine bağlıdır. ix) Hükümetler çok fazla para bastığında fiyatlar yükselir. x) Toplum kısa dönemde enflasyon ve işsizlik arasında kısa dönemli bir ödünleşme ile karşı karşıyadır" (Campbell vd., 2018).

Neoklasik iktisadın yüz elli yıldır kapitalizmin savunusunda oynadığı tarihsel rolün dayanakları olan bu sıralanan değişmeyen özelliklerinde, Korkut Boratav'ın sözleriyle, "gerçeğe durmadan yaklaşan, fakat bir türlü ulaşamayan bilimin eksikliklerini, bocalamalarını ve yetersizliklerini değil, 'keşfinden' hemen sonra mükemmelliğe ulaşan ve yüzyıldır esas tahliline -'kusursuz' olduğu için- hiçbir ilâve yapılamayan, sadece kapsamı genişletilerek katkılar yapılan bir özellik görüyoruz; bu, kuşkusuz, âletlerinin ötesinde özü ile de mantığın ve özellikle matematiğin yanılmazlığı ve mükemmelliğidir. Bilim değildir" 
(Boratav, 1983: 11). Normatif bir yönetimsel akıldır. Bu genişleyen normatif yönetimsel aklın kapsamı içinde esas olarak kamu maliyesi ve iktisadi olmayan sosyal alanlar ve ilişkiler yer almaktadır. Rasyonel bireyin seçimleri ve davranışları iktisadın temel konusu haline gelirken değerin fayda teorisi, mübadele perspektifinden fiyat teorisi, marjinalist yaklaşım, yöntemsel bireycilik, öznelcilik, tüketimin ve mübadelenin ekonomiyi anlamak için temel analiz birimleri haline gelmesi neoklasik iktisadın katı çekirdeğini ve yönetimsel aklını oluşturan unsurlar ve varsayımlar olarak bu kusursuz ama gerçek dışı düşünce yapısında sürekliliğini korumuştur. Neoklasik maliye teorisi hem 18701930 arasında hem günümüz neoliberal iktisat teorisinde tüm bu yukarıda sayılan unsurları gerektiğinde modifiye ederek ve kapsamını genişleterek kamu ekonomisine uyarlanmasından ibaret bir ekonomi teorisidir. Kamu ekonomisinin hacmini ve eylemini sınırlamaya dönük yönetimsel ilkeden hareket ederek özellikle Mankiw'in son iki ilkesi izinde işçi sınıfı, ücretler ve kamusal istihdam politikaları üzerinde daraltıcı etkiler yaratmayı amaçlayan bir normatif sosyal ekonomi teorisidir.

1870 ve 1930 arasında neoklasik iktisat ve maliye teorisi 1. dünya savaşına kadar oluşum ve gelişim aşamasını yaşamış, sonrasında Keynes'e kadar iktisat teorisinde dogmatik üstünlüğünü kurmuştur. Eşitsizliklerin, refah sorunlarının ve devletin savaş boyunca ekonomideki ağırlığının artışı karşısında bu yıllar boyunca neoklasik iktisadın ve onun dönüştürdüğü liberal tutum içinden neoklasik maliye doğmuş ve gelişmiştir. Neoklasik maliye teorisi farklı kuramsal ekollerden oluşmaktadır ve bu kuramların bütünlüklü bir şekilde anlaşılması için literatürde çeşitli işlevsel yaklaşımlar ileri sürülmüştür. Bunlar arasında şunlar belirgin biçimde ön plandadır: i) Yeni bir öneri olarak Orhan Kayaalp'in (2004) neoklasik ekollerin Avrupa'da marjinalist devrimin izinde kamu ekonomisine marjinalizmi uygulama biçimindeki farklılıklara ve gelişim gösterdikleri ülkelere göre sınıflandırması (Britanya-fedakârlık yaklaşımı, İsveç-kolektif seçim yaklaşımı, İtalya-fayda yaklaşımı, Avusturya-öznel değerlendirme yaklaşımı ve bunların karşı kutbuna düşen Almanya-organik yaklaşım); ii) Musgrave'in (1985) maliye düşünce tarihi içinde konulara göre sunduğu sınıflandırıcı analiz; yine iii) Musgrave ve Peacock'ın (1958) kamu harcamalarını analizde dişarıda bırakan ödeme gücü yaklaşımı, toplumsal isteklerin öznelci değerlendirmesine dayanan fayda yaklaşımı, sosyal güdü ve kişisel çıkar ilişkisi, kolektif istekler ile grup ihtiyaçlarını konu edinen yaklaşımlar ile neoklasik teorinin dişına düşen ve Alman tarihsel perspektifi biçimindeki sınıflandırmaları söz konusudur.

Tüm bu sinıflandırmaların gösterdiği ortak tanımsal nokta neoklasik maliyenin marjinalizmin fayda teorisi içinde şekillenmiş ve fiyat teorisine bağlı olarak kamu ekonomisini çözümleyen bir iktisadi teori olarak gelişmesidir. Klasik politik iktisat düşüncesinde gelişen maliye teorilerinden farklı olarak sınıf ve sınıfsal ilişkiler yerine bireyin doğası, istekleri, tercihleri ve davranışları öznel 
ve kolektif sahada esas analiz birimi haline gelmiştir. Klasik politik iktisatta görülen kapitalist, işçi ve toprak sahibi gibi aynı zamanda politik olarak tanımlanmış sınıflar yerine gelir/harcama düzeylerine ve tercihlerine göre farklılaşan bireyler ve bireylerin öznel ve kolektif tercihleri maliyenin konusu olmuştur. Devlet sorunsalı açısından bakıldığında, devletin mali gücünün sınırlanması klasik politik iktisatta olduğu gibi yine amaçtır. Ancak bu amacın arkasındaki iktisadi rasyonalite farklıdır. Klasik politik iktisattaki piyasa ve devlet ekonomisi karşıtlığı sürdürülür ancak bu devlet-ekonomi karşıtllı̆̆, maddiliği içinde kavranan sivil toplum soyutlaması aradan çıkarılarak, esas olarak spesifik bir indirgemeci birey soyutlaması üzerine temellenmiştir. Bireylerin davranışları ve seçimlerindeki akılcılık müdahaleci devletin mali otoritesini sınırlandırmaktadır, hatta en uç noktada devletin mali otoritesine gerek kalmamaktadır.

Bireyin doğası neoklasik iktisatta ve maliyede hedonisttir. İktisadın bireyi (homo economicus) acıdan kaçan hazzı yakalamaya çalışan, faydasını maksimize etmeye çalışan rasyonel ve kişisel-çıkarına göre davranan bireydir. Bu bakımdan mali sistemin analizi bireyin veri gelir ve fiyat düzeyi karşısındaki davranışlarına, isteklerine, tercihlerine ve seçimlerine odaklanmaktadır. Neoklasik iktisadın fayda teorisi bağlamında bireyin doğasına ilişkin bu tanımı kamu ekonomisi alanına (esas olarak kamu harcamaları ve vergiler konusuna) uygulanarak neoklasik maliye akımı geliştirilmiştir.

Ancak neoklasik teoriler arasında keskin farklıklılar da vardır. Bütün neoklasik maliye teorileri devletin mali gücünü yeniden tanımlarken ve açıklarken her biri analitik tahlillerinde devlete farklı normatif konumlar da vermiştir. Kayaalp'in (2004) ülke sınıflandırması bu bakımdan işlevseldir. Avusturya ve İsveç ekolleri devleti daha güçlü sınırlandıran yaklaşımlar olarak tanımlanabilirken, Knut Wicksell (1896) fayda yaklaşımı tam olarak uygulanırsa devletin görev alanının genişleyebileceğini belirtmiştir. İtalyan neoklasik teorileri de devletin marjinalizme uygun yeni bir formülasyonunu yapmış; Britanya ekolü fedakârlık ve ödeme gücü yaklaşımı ile minimal devleti savunur ve maliyeye marjinalizmi uygularken devletin geliri ve kaynakları yeniden dağıtıcı ve genişlemeci rolüne kapı aralamıştır. Dolayısıyla bireyin doğası konusundaki büyük ortaklığa rağmen, bu bağlamda bireyin iktisadi davranışlarını açıklayan genel bir teori olarak marjinalizmi hepsi sahiplenirken, devlet ve maliye konusunda neoklasik yaklaşımlar çeşitlilik göstermiştir.

Yine Kayaalp'in (2004) sinıflandırmasından hareketle bakıldığında, neoklasik maliye teorilerinin birbirinden ayrıldığı noktalardan biri bireyin teoride yer tuttuğu konum ile ilgilidir. Kimi teoriler mali kararların oluşumunda devlet ve birey arasındaki ilişkiye odaklanır (İtalyan ve Britanya teorileri), kimi teoriler mali kararların (kamu harcamalarının düzeyi, kamu malının fiyatı, vergi yükünün bireyler arasındaki dağılımı ve düzeyi, ekonomideki toplam vergi yükünün 
düzeyi) bireyler arası etkileşimden doğduğunu belirterek (İsveç ve Avusturya) bunu modellerine katarlar. Ancak tüm bu teorilerde bireyi ve bireyler aras1 etkileşimi konu edinen yaklaşımlar arasında farklılıklar olsa da topluma yaklaşımları benzerlik göstermektedir. Toplum neoklasik iktisatta ve maliyede rasyonel-çıkarcı bireylerden oluşur, bu bakımdan toplum (ya da toplumsal grup) bireylerin toplamıdır. Bütünün ya da toplamın parçaya, yani bireye göre kendini ayrıcı bir ontolojik farkı yoktur. Neoklasik maliyecilerin önemli bölümü bireylerin tercihleri ile kolektif (ya da toplumsal) tercihlerin birbirinden ayrılamayacağını iddia etmiştir. Ricardo’nun (1997: 217) yazdığı gibi: "Birey için akılcı olan, ulus için de akılcıdır".

$\mathrm{Bu}$ bakımdan neoklasik maliye teorisinde toplumun ve devletin ekonomisinin incelenmesi bireyin incelenmesinden başlamaktadır. Bir bütün olarak bakıldığında iktisadi ve mali davranış, devletin doğası, toplum ve siyaset gibi tümel (evrensel) kategoriler ve yapılar bireyden hareketle açıklanır. Bu bağlamda neoklasik maliye teorilerine getirilen en önemli eleştiriler şunlardır: Neoklasik teoriler tarih-dışı bir bakış açısına sahiptir; sosyolojik bakışı ya yoktur ya da Pareto'nun sosyolojisinde olduğu gibi önemli ölçüde kusurludur (Swingewood, 1998: 197-205); aşırı mantıksal, indirgemeci ve soyut kurgular içinde realist (gerçekçi) bir bilimsel tahlil yapamazlar; kapitalist ekonominin işleyişini meşrulaştıran yönleri ağıllıktadır; bu bağlamda eleştiri odaklarında yalnızca müdahaleci ya da ekonomiye katılan devlet modeli yer almaktadır; bireye aşırı bir vurgu yapılmaktadır. Bir kısım neoklasik teori (başta İsveç ve İtalyan neoklasik teorileri olmak üzere) devlet kurumları ve politik süreç gibi toplumsal yapıları ve süreçleri analize dâhil ederek odağının kapsamını genişletme gayesinde olmuştur; ancak toplum ve siyaset gibi yapıları ve ilişkileri gerçeklik boyutunda açıklayamamaktadırlar ve bireysel piyasa rasyonalitesinin aritmetik toplamına denk gelen bir devlet aklı ve siyaset soyutlamasina varmışlardır ve sınıf öznellikleri olmayan oy piyasasında politikacı, bürokrat ve seçmenlerden oluşan politik piyasanın aktörleri etrafında siyaset, siyasal alan ve ilişkiler kavramsallaştırmışlardır.

Özetle, neoklasik maliyede eleştirilen ya da yeniden tanımlanan yapı esas olarak sürekli genişleme eğilimi gösteren devlet ekonomisidir. Teorilerin arasındaki farklılıkları gözeterek yaklaştığımızda neoklasik maliyede devletin toplumda, ekonomide ve siyasette oynadığı rol çeşitlilik gösterir: i) Devlet ya bir gerekli kötülük olarak idari bir yapı biçiminde tasarlanmış, ii) ya hiç konu edinilmemiş (özellikle sadece bireye odaklanan yaklaşımlarda), iii) ya da devlet idari bir yapıdan ziyade politik bir aygıt olarak çözümlemelerin içinde yer almıştır. İtalyan ve İsveç neoklasik teorilerinde devlet salt bir idari aygıt olmanın ötesinde demokratik ve liberal bir topluma özgü politik bir yapı ve ilişki olarak çözümlenmiştir. Örneğin İtalyan neoklasik maliye teorilerinde devlet ve devlet adamı (hesap-adamı anlamında) bireysel çıkarcı rasyonalitenin toplamı olarak 
görülmüş ve bir mali güç olarak modellerde yer almış; İsveç ekolünün teorilerinde ise politik yapı devletin ötesinde geniş bir bireyler arası toplumsal düzlemde ele alınmış ve ideal bir düzende (yani oy birliği ilkesine göre işleyen liberal-demokratik yapıda) devletin politik bir güç olarak nasıl işlediğine dair neoklasik formülasyonlar yapılmıştır (Kayaalp, 2004). Belirtildiği üzere, İsveç ekolünün önemli iktisatçısı ve maliyecisi Wicksell fayda yaklaşımı ile devletin faaliyet alanının yeniden tanımlanabileceğini ve bazı görevleri açısından genişleyebileceğini söylemiştir. Bir bütün olarak bakıldığında neoklasik maliyenin analitik araçları ve soyutlamaları şu şekilde belirlenebilir. i) Yöntemsel bireycilik (methodological individualism) ii) Gönüllü mübadele ilişkisine dayanan fiyat teorisi: iii) Marjinal fayda yaklaşımı iv) Öznelcilik ve fayda-değer teorisi. Bunların kamu ekonomisine uygulanmasından neoklasik maliye teorisi doğmuştur.

\section{Kamu Maliyesinin Liberal ve Neoliberal Yönetimselliği}

Neoklasik maliyenin ayrıcı özellikleri Ricardo sonrası iktisadi düşüncenin 19. yüzyıl boyunca geçirdiği dönüşümler içinde gözlemlenmektedir. Özellikle iktisadın konusunun üretimden mübadele alanına ve tüketim ilişkilerine kayması, bunun izinde disiplinler arasılığın, yapısalcılığın ve bütünselci bakışın terki ve tümdengelimsel matematiksel analizin yükselişi ile birlikte iktisadın realizmindeki keskin düşüş kamu maliyesinin yeni epistemolojik çerçevesini ve yöntemsel temellerini oluşturmuştur. Devlet müdahalesi piyasa başarısızlıkları kavramsallaştırmasıyla yerini korusa da, neoklasik maliyenin toplumsal ilişkileri incelediği kamu(sallık) boyutu ekonominin mikro düzeyde tüketim ve mübadele ilişkilerine indirgenmiş ve mali ilişkiler birey-bireyler arası-devlet ekseninde tüketici tercihi teorisi bakımından ve mübadele perspektifinden irdelenmeye başlanmıştır. Klasiklerin kapitalist piyasa ekonomisinde tespit ettiği paradokslar ve siyasal/sosyolojik analizleri, Smith'te ve J. S. Mill'de açık bir şekilde görüldüğü gibi, teorilerinde tutarsızlık olarak görünen paradoksları üretmiş; ancak neoklasik maliye tümdengelimsel niceliksel ve matematiksel araç ve yöntemlerle koşulsuz serbest piyasa savunusunu çelişkilerden azade ideal piyasa toplumu modeli içinde savunmaya yönelmiştir. Neoklasik maliye kapitalizmin yapısal çelişkilerinin hızlandığı bir zamanda indirgemeci ve öznelci bir kuramsal içeriğe ve yöntemsel temele kayarken bir başka sorun alanı içinden ayrıca bunların çözümlenmesi gerektiği anlaşılmaktadır. Neoklasik iktisadın ve maliyenin kapitalist ekonomiyi inceleme alanı ve tarzı değişirken ve aslında devletin siyasal ve idari faaliyet alanı genişlerken, liberalizmin dayandığ 1 ilkelerde ve yönetim aklında meydana gelen büyük bir değişim söz konusudur. Liberal yönetim anlayışındaki bu büyük değişimin gözlemlendiği en somut alan 
kamu maliyesi teorileridir. Dolayısıyla genel olarak kamu maliyesini, özelde neoklasik maliyeye geçiş sürecini farklı bir düzlemde ve perspektifle değerlendirebilecek bir konumlanma noktası daha vardır. Foucault'nun liberalizmi ve neoliberalizmi yönetim aklı olarak incelediği yönetimsellik analitiği bu olanağı sunmaktadır ve maliye teorisini yeni ve eleştirel bir sosyolojik yaklaşımla buluşturma firsatı vermektedir.

Foucault'nun (2013) 'yönetimsellik' (governmentality) kavramiyla vurguladığ 1 ilk nokta 16 . yüzyılda mutlakıyetçi devlet ve merkezi idari sistemlerinin doğuşu ile birlikte 18. yüzyılın ikinci yarısına kadar devam eden süreçte siyasal akılda değişen sorunsallardır. Kilisenin toplumların üzerindeki egemenlik ve yönetimsel gücünün hükümdarlara ve onlara bağlı idari yapılara ve mekanizmalara geçişiyle başlayan yeniçağın siyasal aklında beliren ilk unsur hükümdarın meşruiyetini sağlayan ama aynı zamanda bireylerin haklarını gözeterek hükümdarın gücünü sınırlayan doğal hukuktur. Hükümdarın 'nasıl hükmederim?' sorusuna bir karşılık olan doğal hukuk felsefesi 18. yüzy1lda Kant ve Rousseau gibi aydınlanmacıların yeniden formülasyonu ile liberalizmin temellerini oluşturmuştur. ${ }^{2}$ Diğer taraftan özellikle Almanya'da kamu

2 Foucault 18. yüzyılın ikinci yarısından 19. yüzyılın sonlarına doğru Batı'da süren dönemi hem bir bütün olarak önceki dönemlerden hem de kendi içinde farklı yönlerden ayrıma tabi tutar. Bunlardan ilki Foucault'ya göre insan öznelliği ve deneyimi 18. ve 19. yüzyıl boyunca gelişen insan bilimleri ile farklı bir bilgi sistemi içinde yeniden belirlenmiştir. Statik ve taksonomik bir doğa tarihi anlayışından insanı çevresiyle aktif bir ilişki içinde 'yaşayan' özneye ve 'nüfus'un dinamik (evrimleşen) bir biyolojik unsuru olarak 'biyo-iktidar'ın nesnesine çeviren biyoloji olmuştur. Kamusallığın doğumuyla derinden bağlantısı olacak şekilde insanı 'konuşan' özne olarak tarihselliği ve kültürel koşulları içinde dönüşen ve dinamik bir dil dünyası içinde yeniden belirleyen 'filoloji'dir. Son olarak politik ekonomi merkantilist doktrinin zenginlik analizini terk ederek insanı emek öznelliği içinde 'çalışan' özne olarak yeni bir bilgi sistemi içinde nesnelleştirmiştir (Foucault, 2010: 2-5; 2013: 75; Gürkan, 2016: 100-102). Ricardo ile başlayan dönem bu bilgi sistemi içinde dönüşümler yaratmış; 19. yüzyılın sonu ise marjinalizmin doğuşuna tekabül edecek şekilde bu dönüşüm bir başka epistemik kırılmaya doğru bir eşiği temsil etmektedir. Foucault'nun Kelimeler ve Şeyler'de (Foucault, 2002) açıkladığı ve daha sonra Bilginin Arkeolojisi'nde (Foucault, 1972) yöntemsel yönlerini belirginleştirdiği bu bilgi ve bilme analizi aynı zamanda bilginin/bilmenin iktidar bağlantılarında da bir dönüşümü içermektedir. Foucault epistemik dönüşümler ya da kırılmalar kadar iktidar teknolojilerinin de insan öznelliğinin yeni deneyim biçimlerini ve nesnelleştirme tarzlarını nasıl belirlediğini 1970 ’ten itibaren gündemine almıştır. Bu analizlerinde güncel zamanımızı özellikle ilgilendiren bir saptaması şudur: 18. yüzyılın sanayileşme dönemi üzerinde yükselen 19. yüzyıl bir sefalet ekonomisi yaratmıştır ve politik ekonomi özellikle bu sefalet ekonomisi içindeki işçi sınıfının 
maliyesinin modern öncüsü olarak kabul gören kameralizmde ve polis bilimlerinde gelişen 'nasıl yönetirim?' sorusuna denk gelen Foucault'nun 'yönetim sanatı' adını verdiği bir başka siyasal akıl gelişmiştir. ${ }^{3}$ Derinlikli ve gündelik hayatın içine nüfuz eden mekanizmaları ve kurumlarıyla kapsamlı kamu yönetimi ve düzeni anlamlarını içeren 'polis' ayrıca zamanın politik

durumuna odaklanmıştır. Sınıfsal bir analiz içinde kapitalizmin ürettiği zenginliğin genel bir refah ekonomisine dönüşmemesi sorunsallaştırılmıştır. 20. yüzyıl ise Foucault'ya göre nazizm ve Stalin dönemi ile iktidarın ekonomik sefaletinden öte aşırılığını, büyük devlet yapılarının sorunlarına odaklanmış bir dönemdir. Ekonomi politikaları bu aşırı iktidar sorununa yeni liberal ve eleştirel formülasyonlar geliştirirken özellikle 1968 dönemeci ile insan deneyiminin iktidarın gündelik yaşamı dizayn eden aşırılığından sıyrılma mücadeleleri yoğunlaşmıştır (Foucault, 2019d: 168-170; 2019h: 64-65). Foucault (2015) Biyopolitikanın Doğuşu'nda bu yeni (neo)lieberal ekonomi teorisinin tepkilerinin analizini sunmaktadır. Foucault'nun bilgi ve iktidar teknolojilerinin ve yapılarının dönüşümüne dair sunduğu bu tarihsel çerçevenin içinde izleyen satırlarda açıklandığı gibi kamu ekonomisinin sergilediği dönüşümler de izlenebilmektedir.

3 Foucault siyaseti hukuksal akıldan farklı olarak yasanın yerine normu koyarak yeniden icat etmiş bu yeni politik aklı kameralizm, polis ve disiplinci iktidar üzerinden tanımlar. Yasa toplumu yerine 'norm toplumu'na yönelen bu iktidar için önemli olan ayrım yasal olan ve olmayan, meşru olan ve olmayandan ziyade normal olan olmayan, sağlıklı ve hasta, suçlu ve suçsuz, deli ve akıllı, toplum ile kamusalın dışı arasındaki ayrımlardır (Foucault, 2019b; 2019c). Norm ya da "normalleştirici iktidarı" (Foucault, 2009h: 78) farkl1 alanlarda kurulan bir norm(al) toplumu inşa ederek ayrımların "arayüzeyinde" (Foucault, 2019d) işleme konmaktadır. Foucault Batı tarihinde bir hukuk toplumu ve devleti olarak gelişen modern devletin ve toplumun oluşum süreci paralelinde ayrıca bir norm devleti ve toplumu olarak gelişen siyasal iktidarın diğer yüzlerini ve yüzeylerini keşfetmiştir. Hukuk toplumu ve devleti gibi norm devleti ve toplumu da kapitalizmin gelişimine bağlıdır. Foucault'nun bu iktidar analizi kamu maliyesi disiplininin tarihi için de son derece önemlidir. Kamu maliyesinin bir toplumsal sistem olarak hukuk iktidarı ötesinde norm iktidarının ve bu iktidarın hukuk bilgisinin ötesinde modern dönemde temel bilgisi olan insan bilimleri etrafinda kurulduğunu göstermesi bakımından Foucault'nun çalışmaları ayrıca önemlidir. Foucault'nun çalışmalarında kamu maliyesinin bilgi tarihini norm iktidarının tarihi içinde 19. yüzyılın sonuna kadar izleyebileceğimiz bir analitik çerçeve ve yer yer tarihsel malzeme bulmaktayız. Bu tarihsel malzemelerin en önemlilerinden biri 2015'te Fransızca olarak yayımlanmış ve 2019'da İngilizce literatüre kazandırılmıştır: Foucault'nun Collegè de France'da 1971-1972 döneminde verdiği derslere ait notlar Ceza Teorileri ve Kurumlarl (Penal Theories and Institutions, $2019 \mathrm{~g}$ ) başlığıyla yayımland. Fransa tarihindeki vergi kurumlarına, ceza yasalarına ve isyanlarına odaklanan, bu bağlamlarda modern vergi devletinin doğuşunu irdelediği bu metnin kamu maliyesinin iktidar tarihine dair kuramsal ve olgusal malzeme sunduğunu geçerken belirtelim. 
ekonomisinin içinde geliştiği ve İngiltere'de karşıllğı merkantilizm olan disiplinci yönetim aklı ve düzeneğidir. Yönetim sanatı adından anlaşılacağı üzere hukuksal bir iktidar modeli içinde hükmetmek ve egemenlik kurmaktan ziyade devletin idari, askeri ve mali gücünü gözeten, bireyleri gündelik ve olağan yaşamı içinde bu güçler toplamına dahil eden, diğer devletlerle bu alanlarda ilişkilerini aynı zamanda diplomatik olarak idare eden yönetim aklı ve düzeneklerle ilgilidir. Egemenlik/hükmetmek ve yönetmek arasında başlayan bu farklılıkta ikincisinin giderek önem kazandığı ve politikanın yeniden düşünüldüğü bir çağa girilmiştir. 16. yüzyıldan itibaren hukuksal/hükümdarlık iktidar modelinin ve yazınının gelişimine paralel yönetim sanatı yazını ve teorisi hem toplumsal ve bireysel yaşamın refahını, kolaylığını ve düzenliliğini ilgilendiren somut ve gündelik her tür sorunla hem de devletin askeri ve mali gücünü artırmakla, bunun için bireylerin üretken kapasitesini geliştirmekle meşgul olan pratik işler ve gündemlerle ilgili olarak gelişmiştir. ${ }^{4} \mathrm{Bu}$ çağda

4 Foucault cezalandırıcı ve tıbbi iktidarın tarihini 16. yüzyıldan 19. yüzyılın sonuna kadar incelerken iktidarın egemenlik ya da hükümranlık modelinden farklı bir iktidar düşüncesine ulaşmıştır. Kaynağını hukuktan, egemenden ve devletten alan bir 'yapı' olarak iktidar yerine toplumsal gövdenin tümüne yayılan ve işlemini gündelik yaşam içinde bireylerin davranışlarında, öznellik deneyimleri ve kuruluşlarında gerçekleştiren, 'yapı' yerine bir (toplumsal ve bireyler arası) 'ilişki' olarak iktidar kavrayışı ve teorisi geliştirmiştir. İktidarı yapısal ve özsel soyut karakteristiği ile değil, gündelik yaşamın içinde bireylerin öznellikleri ve davranışları üzerinde strateji ve taktik gibi dinamik edimlerle oluşan çoklu mücadele alanları içindeki oyunlar gibi kavrayan, buna göre sürekli bastıran bir negatif iktidar yapısı yerine, öznellikleri ve davranışları pozitif olarak üreten, üretirken iktidar ilişkilerini tersine çevirebilecek direnişler yaratan ilişkisel bir iktidar kavrayışı geliştirmiştir (özne ve iktidar ilişkisini tarihselliği içinde hakikat, Aydınlanma, mekân, etik, siyaset gibi çoklu bağlamlardaki kapsamlı bir analizi için bkz. Foucault, 2019a). Foucault bu yeni iktidar kavrayışını, gündelik yaşamın makro ve mikro düzeyindeki siyasal, iktisadi ve etik yaşamı birleştirmeye imkân tanımış yönetim kavramı ile daha gelişkin bir analiz düzeyine taşımıştır. Foucault'nun iktidar ve yönetim analitiği geleneksel iktidar anlayışını ters yüz ederken kimi merkezi kavramları da (örneğin ‘özgürlük') yeniden tanımlamıştır. Kamu maliyesinin 'kamu'su bunlardan biridir. Foucault kamu ve kamusallığ Aydınlanma geleneğinin bir parçası olarak doğan bu kavramları, modern iktidarın yeni uzamı ve gözetleyen disiplinci iktidar ilişkilerinin yeni tarzı olarak tanımlamıştır (Foucault, 2019e). Bu tarihsel analitik çözümlemeler kamu maliyesini bir yönetim ve iktidar ilişkisi olarak yeniden değerlendirmeyi mümkün kılmaktadır. Üstelik bir bilgi sistemi olarak kamu maliyesinin hem kendi iktidar tarihini yeniden tanımlayabilme hem de modern iktidar ve yönetim ilişkileri içindeki konumunu belirleme yolunda Foucault bir yol göstericidir. Ülke ekonomilerinin disiplin yapısını ekonomi boyutunda kuran neoliberal kamu maliyesi politikalarının, kurumlarının ve bilgi sistemlerinin yeni tarihsel eleştirisi iktidar-bilgi ilişkisini tarihsel olarak anlamaktan 
disiplin devletin yeni yönetim aklına bağlı olarak gelişen, toplumsal düzenin ve refahın sürdürülmesini gözeten, bireyin gelişim potansiyelini ve gücünü devletin gücüne bağlayan katı bir hiyerarşik ve kontrol sistemini içeren bir iktidar kipiydi. Foucault'nun 'yönetimsellik' olarak tanımladığı süreç 16. yüzyıldan itibaren gelişen bu yeni siyasal aklı tarif eder ve hukukun yanında tamamlayıcısı olarak değil, aslında devletin gücü ve toplumun refahı için ona karşı da gelişen önce 'disiplin' sonra yeni 'güvenlik' iktidarı olarak liberalizmin iktidar modellerine denk gelmektedir. Konusu geleneksel siyasal kategoriler olarak vatan anlamında toprak parçasına, halka ve tebaaya hükmetmek olmayan, toprağı ve üstündekileri idari faaliyetin nesnesi olarak gören, bu bakımdan 'nüfus' (population) kavramını kendine özne ve hedef olarak seçen, yönetim faaliyetini harekete geçirecek ve hakikatini üretecek bilgi biçimleri olarak başta 'istatistik' (statistics/state science) ve tarihsel sıra içinde daha sonra 'insan bilimleri' (human sciences) gibi ampirik uygulamalı bilimler olan yeni bir siyasal akıl ve süreç Foucault tarafından yönetimsellik olarak adlandırılmıştır.

Yönetimsellik bu bakımdan hem bir tarihsel yaklaşım hem de siyasal aklın kavrayışına dair geleneksel yaklaşımlardan ayrılan farklı bir analitik çözümlemedir. Örneğin Foucault hükümdarlık, disiplin ve yeni güvenlik iktidar modeli olarak liberalizmi bir tarih kronolojisi içinde sıralayıp kendi içlerinde onları ayırıcı özellikleriyle incelerken, bu üç iktidar modelinin birbirinin içine geçerek geliştiğini söylediğinde modern siyasal düşünceyi ve sistemi bir iktidar kompleksi olarak anlamak bizi analitik çözümleme düzlemine taşımaktadır. $\mathrm{Bu}$ analitik düzlemde diğer önemli bir nokta iktidarın kaynağı olmasa da, temel bağıntısı olarak bilginin gelişim biçimleri ve bunun makro ve mikro düzeylerde iktidar etkileridir. Foucault’nun sunduğu yönetim tarihine bakıldığında kilisenin yönetiminden, devlet aklına, oradan devleti sınırlandıran bir yönetim modeli olarak aynı zamanda içinde sivil toplum ve piyasa düşüncesini barındıran doğa ve doğal düzene, en sonunda da 19. yüzyıldan itibaren bir yönüyle hümanizme bağl olarak insan aklına ve otonomisine dayanan piyasa-devlet-toplum ilişkisini insan-merkezli yeniden tanımlayan bilgi ve yönetim modeli tarihi görülmektedir.

geçmektedir. Foucault'nun deyişiyle: “Bilimsel bir bilginin gelişimini, iktidar mekanizmalarındaki değişimler dikkate alınmadan anlamak imkansızdır. Tipik örnek, ekonomi bilimidir . . . İktidar mekanizmalarını düşünmeden bilimsel bilginin ilerlemesi düşünülemez" (Foucault, 2019f: 247). Foucault'nun bu analizi izlendiğinde kamu maliyesinin bir bilgi ve toplumsal sistem olarak kamu ve devlet iktidarı ile yeniden ilişkilendirilmesi mümkündür. İzleyen satırlarda Foucault'nun iktidar analizinden yönetim analitiğine geçtiği 1970'lerin sonundaki liberalizm ve neoliberalizm üzerine dersler takip edilerek neoklasik iktisat ve maliye teorisinin klasik liberalizmden farklılaşarak neoliberalizme uzanacak şekilde bu ilişkilendirmeyi nasıl yaptığına dair bir analiz çıkarılmaktadır. 
Anlaşılacağı üzere, devletin varlığını yine kendisine referansla tanımlayan devlet aklı seküler bir yönetim ve bilgi biçimi olarak merkantilist iktisadı ve kameralizmi içermektedir. Newtongil paradigmaya bağlı olarak gelişen ve içinde disiplinci iktidar kipinin unsurlarını taşıyan ve geliştiren doğalcılığın 'bilgiiktidarı' politik ekonomidir ve liberalizmi bir yönetim modeli olarak inşa etmiştir. Neoklasik iktisat ve maliye ise liberalizmin kendi içinde dönüştüğü insan aklına dayan bir bilgi biçimi ve yönetim modelidir. Özetle din/hukuk ${ }^{5}$, devlet (akl1), doğa (akl1)/sivil toplum (kamusal akıl) ve insan (aklı ve psikolojisi) tarihte yönetimin modelleri ve bu modellerin dayandığ ilkeleri üreten bilginin kaynakları ve hedefleridir. ${ }^{6}$ Foucault'nun yönetim tarihinin bir analitik olması dolayısıyla şu gerçekten kaynaklanmaktadır: Siyaseti bu düşünme tarzı bilgi, yönetim ve iktidar ilişkilerini makro ve mikro düzeylerde anlaşılmasını mümkün kılmaktadır; bir soykütüğü modeli içinde bu bilgi, iktidar ve yönetim kaynaklarının ve hedeflerinin birbirlerine geçerek ilerleyişini süreklilikleri ve süreksizlikleriyle gösterebilmektedir.

Foucault'nun yönetime odaklanan bu çok boyutlu siyasal, tarihsel ve sosyolojik çözümlemesinin birçok sosyal bilim disiplini için yeni çalışma alanları açan yönleri bulunmaktadır. Bunlar içinde iktisadın önemli bir yeri vardır çünkü doğal hukukun karşısında doğanın bir yönetim ve bilgi modeli ve kaynağı olması 18. yüzyılın ikinci yarısında Smith'in en büyük temsilcisi olduğu politik ekonomiyle bağıntılıdır. İnsan aklının bir yönetim, iktidar ve bilgi modeli, kaynağ 1 ve hedef olması ise 19. yüzyılın son çeyreğinde psikoloji ve psikanalizdeki yeniliklere tekabül eder ama asıl olarak bunun taşıyıcısı ve 'bilgiiktidar' formu iktisadın yeni neoklasik modelidir. Neoklasik modelin insan aklına ve psikolojisine dayalı liberalizminin yeni hedefi nüfustan ziyade rasyonel ve psikolojikleştirilmiş birey aracılığıyla devletin kendisi özellikle maliyesi

5 Foucault 16. yüzyıl öncesinde iktidar ilişkilerini yöneten kilisenin ve örgütlü dinin sunduğu iktidar modelini hukuksal iktidar modelinden ayırmamaktadır (Foucault, 2019b). İktidarı yasaklama, izin verme, bastırma, tahakküm, ve egemenlik nosyonlarına göre düzenleyen bu iktidar modelinden Foucault iktidarın pozitifliğini vurgulamak üzere ayrılmaktadır.

6 Klasik ya da Rönesans ile başlayan çağ yeni bir 'akıl' çağıdır. Foucault dinsel akıldan sıyrılan bu seküler aklın Batı'daki evrimini Descartes ile başlayan felsefenin akıl çözümlemesini ve övgüsünü izleyerek ele almak yerine aklın bu faklı düzlemlerde kurulan 'öykü’sünü karşıtı olan deliliğin tarihi ile çıkarmıştır. Batı'da aklın keşfini deliliğin keşfi, deliliğin tıbbi bir bilme biçimi ile yeniden tanımlanışı ve delilerin tecrit edilerek tımarhanelere kapatılmasıyla mümkün olduğunu 1961 tarihli Deliliğin Tarihi'nde (Foucault, 2006) göstermiştir. Foucault delilik, suç ve cinsellik üzerine tarihsel araştırmaları sırasında iktidarın bu dışlayıcı özelliğini bireyler dışlanırken nasıl içerildiği ve toplumsal yaşam içinde nasıl yönetildiği temalarına doğru genişletmiştir. 
olmuştur. Neoklasik maliye bu bakımdan 'neoklasik liberalizm'in doğumunda ve şekillenmesinde en önemli yönetimsel hedeftir ve yeni yönetim aklının önemli aparatlarından ve hakikat sistemlerinden biri olmuştur. Neoklasik ve neoliberal yönetimselliğin hem hedefi hem de mantığının ve kültürünün dolaşıma girdiği bir bilgi rejimi ya da düzeneği olarak kamu maliyesi söz konusudur.

Foucault bu bakımdan liberalizmi yönetimsellik tarihi içinde bir siyasal ideoloji olarak değil, yönetim tarihi ve aklı olarak inceleyerek yeni bir analiz düzeyi ve yöntem açmıştır. Kamu maliyesinin liberalizmde kuramsal ve olgusal tarihini farklı bir analitik düzlemde irdeleyebilecek yenilikçi bir analiz tarzını sunmuştur. Buna göre, liberalizm üç temel özelliği ile anlaşılabilir ve tanımlanabilir: "[P]iyasanın doğrulaması, fayda hesabıyla yönetimselliğin kısıtlanması ve son olarak da Avrupa'nın küresel piyasa sayesinde sınırsız bir ekonomik kalkınma bölgesi olarak konumlanması. Bunların toplamına liberalizm diyorum" (Foucault, 2015: 52). Smith'in politik ekonomisi 18. yüzy11 klasik liberalizmde gelişen yönetim aklına bir kaynak sunmuştur ve düşünürün maliye teorisi de bu yönetim aklına dayanır ve ona göre şekillenmiştir. Ancak Smith'in liberalizme özgü olarak devletin yönetimselliğini sınırlama projesi bir ilke olarak karşımıza çıksa da, Milletlerin Zenginliği'nde kamu maliyesine bakıldığında sınırlamadan ziyade devlete uygarlaşma yolunda tanıdığı işlevler çok daha fazla ön plana çıkmaktadır. Bu işlevler Foucault'nun belirttiği gibi doğal bir alan olarak piyasayı gözlemleyerek devletin keşfettiği, bu anlamda kendini piyasaya göre yöneten, sınırlandırma ilkesini bu işlevleri üzerinden kendi içinde bulan bir yönetimsellik tarzıdır. Uygarlık bir ilerleme olduğundan bu sınırlama Smith için tarihsel olarak değişebilen bir ölçeğe ve içeriğe sahiptir. Smith'in harcama, vergi ve borç üzerine olan Milletlerin Zenginliği'nde Kitap 5 'teki maliye tarihine ve analizine bakıldığında klasik liberalizmin maliye teorisinin neoklasik liberal ve neoliberal maliyeden ayrılan yönleri rahatlıkla görülebilir. Her şeyden önce bütünselci, gözleme ve tarihsel bilgiye dayalı realist çözümlemeler, özellikle sosyolojik çerçeve ön plandadır. $\mathrm{Bu}$ sosyolojik çerçevede devlet ve birey arasında sivil toplum ve onun tarihi yer almaktadır. Toplumun evrimsel şeması içinde insanın doğal eğilimi olan mübadelenin sonucu olarak gelişen iş bölümü ile bağıntısında varolan kamu maliyesi sistemi ve teorisi Smith için saf politik ya da iktisadi bir konudan öte, sivil toplum düzleminde devlet ile (birey ve nüfus olarak) insanın çıkarlar düzleminde yönetiminin tarihte nasıl olduğu ve uygar toplumda nasıl olması gerektiği üzerinedir.

Foucault liberalizmin fayda hesabına dayalı çıkar oyunu olduğunu yazmaktadır:

Yönetim aklının 18. yüzyılın başında oluşan modern yapısı, yani temel özelliği kendi kısıtlamasının ilkesini aramak olan yönetim aklı, çıkar 
üzerinden işleyen bir akıldır . . Y Yönetim aklının uyması gereken çıkar ilkesi, bireysel çıkarlar ve müşterek çıkarlardan, toplumsal fayda ve ekonomik kârdan, piyasa dengesi ve kamusal güç düzeninden oluşan bir oyundur . . . Bu yönetim aklında yönetim, çıkarları manipüle eden bir şeydir (Foucault, 2015: 40-41).

Albert O. Hirschman (2008: 36-38, 54, 63-66) da çıkarın liberalizmde tutkuların devlete, topluma ve bireye zarar veren duyguların/tutkuların "terbiyecisi” olarak geliştiğini, fayda hesabına dayanan bir öngörülebilirlik ve denetim mekanizmaları yarattı̆g için devletin çıkarlara dayalı olarak kendini, toplumu ve bireyleri yönettiğini, çıkar sisteminin devlette güç zehirlenmesinin önüne geçerek gücü ulusal güvenliğe, açgözlülüğü zenginliğe ve sermaye birikimine, kamusal düzeyde de bireysel zenginliği bolluk yaratan bir duruma çevirdiğini yazmaktadır. Yani çıkar devlet, toplum ve birey arasında üçlü oynanan bir oyundur ve Smith ile klasik liberalizmin çerçevesinde kamu maliyesinin siyasal işlevini bu oyun metaforu çok yerinde özetlemektedir. Smith için kamu maliyesi kamunun devlet ve toplum biçiminde yapısal bölünüşünde anlaşılabilecek bir çıkar sistemi yönetimidir. Smith'in iktisadi ve mali çerçevesinde birey ve ekonomi topluma ve toplumsal mutluluğa tabi onun denetimde olan bir alt sistemdir. Diğer bir deyişle, bireylerin toplumsal ve sınıfsal varoluşu vardır ve bireysel-özel çıkarlar sivil alanın içindedir. Smith ekonomiyi devletten ayırmıştı ancak toplumdan ayırmamıştır çünkü ticaret bir karşılıklı zenginlik sistemi olarak ancak toplumsal ilişkilerin kamu çıkarını gözeten sistemi içinde ve denetiminde gerçekleşebilir. Toplumun denetimi etik düzlemdeyken devletin denetimi idari ve siyasal alan ve işlevler içinde gerçekleşir. Kamu maliyesi bu bakımdan devletin çıkarını, toplumun çıkarını (toplumsal mutlulukta ifadesini bulan kamu yararını) ve ekonomik alanda bireylerin çıkarını yöneten ve bunların siyasal açmazlarını çözen ve yöneten bir liberal yönetimselliktir. Kamu maliyesinin Smith ve klasik liberalizmdeki etik ölçütü bu bakımdan toplumsal mutluluktur, yani kamu refahıdır. Bu mutluluk neoklasik iktisadın ve maliyesinin bireylerin tüketim faaliyetine bağlı olarak arzularının doyumuyla ilişkili değildir. Francisco Vergara'nın (2006: 99-105) yerinde tespitiyle söylenirse, klasik faydacı ilke mutluluğu toplumsal boyutuyla anlarken bunu aynı zamanda bir süreç içerisinde görmektedir. Bu süreçte mutluğa giden yol, mutluluğun yaşandığı an ile geleceğin bu yöndeki belirli bir teminatını da içeren bir yönetimsellik içinde şekillenir. Smith'in uyumlu ve iyimser dünyasında mutluluğun üretimi, yaşanması ve bolluğu önemliyken neoklasiklere gelindiğinde iktisadın ve maliyenin konusu bireylerin bilişsel kapasitelerine ve rasyonel seçimlerine, hazcı ve egoist doğasına bağlı olarak arzuların anlık doyumuna indirgenmiştir. Üretimsel faaliyetin bir sonucu olarak düşünülen toplumsal mutluluk ekonomisinden bireysel arzu ekonomisine geçiş iktisat teorisinde emek-değer teorisinden fayda değer teorisine ya da üretimden 
tüketime kayış olarak bilinir, ancak bu geçişin liberal yönetimsellik açısından anlamı yönetim modelinin, ilkesinin, hedefinin ve aklının üretimsel ve kamu yararı nosyonundan tüketimci bireysel akla ve çıkara indirgenmesidir. Bu liberal yönetimsellikte ve maliyenin yönetim sanatında önemli bir kaymaya işaret etmektedir: çıkar sistemi bireysel çıkara indirgenmiştir. Smith için de bireysel çıkar önemlidir ve onu devlet ile toplum çıkarından ayırmıştır, ancak çıkar oyununun karmaşık yapısında kapitalizmin paradokslarını ve asimetrik güç ilişkilerinden kaynaklanan olumsuzluklarını görerek sistem eleştirisini içeren ve sistemi düzelten mali işlevleri tartışmaya açabilmiştir.

Liberal yönetimsellikte klasikten neoklasiğe oradan neoliberalizme geçişte ara durak Keynes'in düşündüğü gibi Foucault açısından da Ricardo'dur, ancak iktisat teorisi açısından değil, liberal yönetimsellikteki bir kaymanın ismi olarak Ricardo önemlidir. Değerin Smith’teki mübadele perspektifinden hükmedilen emek biçimindeki ifadesini iptal ederek üretimin nesnel maliyet unsuru olarak emeği gören Ricardo değer teorisinde Foucault'ya göre "sonlu insanı" politik ekonominin içinde icat etmiştir (Foucault 1972: 275-286; 2002: 279-280; 2011: 28). Sonlu insan kapitalist üretimde tükenebilen biyolojik bir varlıktır. Kapitalist sistemin durağanlık gösterme eğilimini düşündüğü gibi Ricardo ayrıca insanı da yalnızca Smith’te olduğu gibi eşitler arası ilişkinin özgür mübadele bireyi olarak değil, üretimde tükenebilir biyolojik bir varlık olarak görmüştür. $\mathrm{Bu}$ tam da "kanun ve düzen, devlet ve sivil toplum, yaşam politikası" (Foucault, 2015: 65) ilişkisinde liberalizmin biyopolitikasına açılan kapıdır ve kamu maliyesinin işlevi sermaye birikimini sağlarken insan yaşamını bu biyopolitik komplekste sürdürmesidir. Birikim işçilere özgü biri durum olmadığı için bu sürdürme minimumda hayatta bırakma yönetimidir; nitekim Ricardo kamu harcamasını Say'nin sistemine uygun olarak tamamen bu kompleksin dışında bırakmıştır. Piyasa fetişizminin başlangıç koşullarında Keynes'in Ricardo'yu görmesi ya da Karl Polanyi'nin (2001: 32) Alman faşizmini anlamak için Ricardo zamanındaki İngiltere'ye dönülmesi gerektiğini düşünmesi liberal yönetimsellikte kapitalizmin kas sistemine dayalı bu üretimsel modelinde sermaye lehine (rasyonel/egoist) bireysel çıar sistemine teoride ve pratikte merkezi önem verilmesiyle ilgilidir. Neoklasik yönetim modeli ve aklının vazgeçtiği şey ise bireysel çıkarın önceliği değildir; tersine bunu radikalleştirerek kapitalizmin kas sistemine dayanan üretim modelidir ve bireylerin biyolojik varlığının yerine bilişsel, psikolojik ve duyusal kapasitesini geçirerek rasyonaliteye ve duygulara, arzuların sınırsız isteklerine ve doyum arayışına bağlı olarak mübadele ilişkilerindeki tüketimi yerleştirmiştir (Stiegler, 2012). Neoklasiklerin Smith'ten farklı olarak toplum yerine daha fazla devlet ile ilişkilenmesi aslında bireysel tüketimin, arzunun ve aklın yönetim modeli, hedefi ve bilgi kaynağı olmasıyla ilgilidir. Tarihte Hobbes'tan itibaren bireye indirgenen düşünce sistemleri devlet ile bütünleşme eğilimi göstermiştir. Smith'in klasik liberalizmi ne kadar 
sosyolojikse ve kamu maliyesi kamu yararını gözeten sosyolojik ve politik bir içerikteyse, neoklasik maliye birey-devlet ilişkisine ve bütünleşmesine vardığında, inkâr etse de, o da faklı bir yönden politiktir. 20. yüzyılın faşizmlerine ve despotizmlerine neoklasiklerden destek gelmesi bu tüketimci yönetimselliğin iç mantık yapısına bağlıdır.

Foucault'nun (2015: 105-107, 188-190) neoklasik iktisat üzerine çok daha önemli bir tespiti de şudur: Marjinalist dönüşüm sonrasında ortodokslaşan iktisat inceleme alanını insanın davranışlarına indirgerken aynı zamanda neoliberalizmin Keynes'e karşı icat edilmesinde üç temel yönetimsel fikri icat etmiştir. Bunlardan ilki iktisadın konusunu mübadelede eşitlikten rekabete kaydırmasıdır. İkincisi klasiklerin doğalcılığı yerine piyasanın inşasının gerekliliğini ve bunun temeline insan eylemini koymasıdır. Üçüncüsü kendinin girişimcisi olarak emek düşüncesinin gelişimidir. Rekabet ve girişimcilik klasiklerde kapitalistlerin hareket tarzını tanımlarken neoklasiklerden itibaren neoliberalizme uzanarak insanın temel ve yaygın varoluşu olmuştur. İnsan eyleminin inşacılığı ve piyasayı doğal sistem olarak değil de inşa edilmesi gereken bir alan ve yönetim kaynăg 1 olarak görülmesi neoliberalizmin özellikle ordoliberalizmdeki ayırıcı özelliğidir. Tam rekabette soyut bir merkez olarak fiyat yapıcı ve saklı planlamacı düşünce (Bénicourt ve Guerrien, 2017: 66) burada hukuk devleti biçiminde ayrı bir önem kazanmaktadır. Girişimciliğin kapitalist sınıfa özgü sınıfsal ekonomik dar anlamından sıyrılıp önce emekçiye sonra ekonomik olmayan tüm öznelliklere yayılımı neoliberalizmin diğer bir temel özelliğidir. Foucault (2015) bu düşüncelerin gelişimini erken neoklasik iktisatta gözlemlemektedir. Neoklasik ve neoliberal maliyenin yönetimsel eksenlerini ve ilkelerini tanımlayan bu kaymalar aynı zamanda neoklasik iktisat ile neoliberalizm arasındaki derin bağlantıyı da göstermektedir. Dolayısıyla kamu maliyesinin neoliberal yönetimselliği klasik liberalizmden neoklasik liberalizme ve iktisada geçiş sürecinde şekillenmiştir.

\section{Sonuç}

Foucault'nun yönetimsellik tarihi ve analitiği kamu maliyesinin tarihini ve teorisini farklı bir perspektifle değerlendirebileceğimiz bir çerçeve, yöntem ve araçlar seti sunmaktadır. Buna göre kamu maliyesi kapitalist ekonominin ve piyasanın işlevsel bir parçası olmasının yanında ve ötesinde liberalizmin esas yönetimsel aracı ve hedefi olarak yeniden ele alınabilmektedir. Buna göre, (neo)liberal normların, akılsallığın ve yönetim tekniklerinin hükümdarlıkdisiplin-güvenlik iktidar kompleksinde toplumsal yayılımını iktidarın normatif yönlerini azaltarak sağlayan bir yönetimsellik aparatı (dispozitifi) olarak kamu maliyesinin yeni bir işlev ve anlam içeriğini yakalayabiliyoruz. Kapitalist ekonominin dört temel özelliği ile -piyasa için meta üretimi, özel mülkiyet, 
bireysel çıkar ve ücretli emek sömürüsü (Hunt ve Lautzenheiser, 2016: 29-32) Foucault'nun liberal yönetimin tanımlayıcı üç ilkesi -hakikat alanı olarak piyasa, fayda-çıkar hesabı ve dünyayı sınırsı piyasa haline getiren ticaret ve sermaye birikim modeli- birbirinden farklı görünmemektedir. Diğer taraftan Foucault kapitalizmin birikim, bölüşüm ve sömürü sisteminin iktisadi düzenekleri yerine bunların içine yerleştiği liberalizmin yönetim ilkelerini, aklını ve araçlarını incelemiştir. Kapitalizmi tanımlayan ve yön veren unsurların liberal yönetim aklı ve modeli için nasıl normatif ilkeler ve araçlar haline geldiğini göstermiştir. İncelemesinde liberal yönetimselliği kapitalist ekonomiden ayrıştırarak Foucault liberalizmin bir yönetim modeli ve aklı olarak dayandığı piyasanın yönetim için bir doğrulama alanı haline geldiğini, politik ekonominin bu hakikat sistemini üreten bilgi-iktidar kaynağı olduğunu tespit etmiş ve bunlara göre devlet aklının, toplumsal yaşamdaki öznelliklerin ve davranışların nasıl yönlendirildiğini belirginleştirmiştir. Kamu maliyesi sistemi ve düşüncesi bu çerçevenin içine dâhil edildiğinde kapitalist ekonominin birikim, bölüşüm ve sömürü sistemi için nasıl doğrudan işlevsel olduğunu değil, liberal yönetimsellikte piyasa hakikatine nasıl bağlandığı, politik ekonomi çerçevesinde bu hakikati nasıl ürettiği ve devlet-özne genel yönetimine bunu nasıl yayarak (neo)liberal yönetimselliği inşa ettiği sorunu analize açılmaktadır.

Liberalizmin bir yönetimsellik tarzı olarak temel sorunu kapitalist ekonominin yapısından kaynaklanan tehlikelerin özgürlüklerle yönetimidir. Foucault için liberalizm bir özgürlük ve güvenlik oyunudur (Foucault, 2015: 56). Güvenlik tehlikeyi ortadan kaldırarak bugünü ve geleceği teminat altına alan bir yönetimsel araç değildir. Tersine güvenlikçi liberal yönetimsellik riskleri ve belirsizlikleri olay akışının seyrine bırakarak bu tehlikeye katılmak için özgürlükleri çoğaltır ve teşvik eder. Özgürlük bu bakımdan liberalizm için bir insan hakkı değil, risk ve belirsizlikleri ve tüm tehlikeli yaşam formunu bireyin çıkar-fayda hesabına bırakarak yönetmek için bir teknolojidir. Foucault'ya göre ekonomik ve siyasi özgürlüklerin çoğaltılması ve teşvik edilmesi kapitalist yönetimi büyüyen bir maliyete taşıyabilir. Bunun bir çözümü liberalizmde sıkı bir denetim ve disiplin düzenidir. Bu sıkı ve disiplin denetimi Keynezyen liberal yönetimsellikte Zygmunt Bauman'ın (2017) kavramsallaştırmasıyla 'katı modernliğe' denk gelen bir toplumsal bürokratik yönetimken, 'akışkan' bir yönetimsellik olarak 1980 sonrası neoliberalizmde ise disiplin modelini de aşan otoriterlik rejimidir. $\mathrm{Bu}$ bakımdan liberalizm ve neoliberalizm Foucault'nun kavramsallaştırmasıyla hükümdarlık-disiplin-güvenlik iktidar kompleksine yerleşmektedir. Ağırlıkları koşullara göre değişirken kamu maliyesi tarih içinde bu üç iktidar tipine göre biçim ve içerik almıştır. 18. yüzyılın son çeyreğinden itibaren kamu maliyesi liberal yönetimselliğin parçası olarak özgürlük-güvenlik oyununa bağlı gelişmiştir. Disiplin ve hükümdarlık iktidar yapıları ve unsurları ise bu özgürlük-güvenlik oyunundan hiçbir zaman ayrılmamıştır. 
Bu inceleme bize kamu maliyesinin her zaman ve sadece saf bir liberalgüvenlik tipi iktidar modeline göre değil, klasiklerden neoklasiklere, Keynezyenizmden neoliberalizme dek disiplin ve hükümdarlık tipi iktidar modellerine göre de şekil ve içerik kazandığını göstermektedir. 1973 devletin mali krizi aynı zamanda Keynezyen liberal yönetimselliğin ve bu yönetimselliği ayakta tutan bu üç iktidar modelinin eklemlenme tarzının kriziydi. Foucault'nun (2015: 60-61) liberalizmin ve kapitalizmin krizlerinin ayrışabildiği tespitinden hareketle şu söylenebilir: 2008 krizi neoliberalizmin krizi olarak nitelendiğinde anlaşılan yine sadece kapitalist ekonominin kârlılık, birikim ve borçluluk krizi değildir; onu ayakta tutan ve hayata geçiren geniş iktidar kompleksidir. Krizin üzerinden on yıl geçmesine rağmen iktisadi etkilerinden ziyade siyasi etkilerinin daha fazla hissedilmesinin ve konuşulmasının bir önemli sebebi neoliberalizmin iktidar kompleksindeki kayma ve çatlamadır. Alternatif ise Foucault'ya göre ne bu kompleks içinde keşfedilebilecek ne de herhangi bir yerde verili ve kayıtlı bir şeydir. Ancak direnme etiği içinde icat edilebilecek bir yeni oluşumdur. Foucault'nun perspektifinden kamu maliyesi icat edilmesi gereken alternatifin hem koşullarından hem de aşılması gereken iktidar aygıtlarından biridir. Foucault'nun analitiği bizi yalnızca farklı değil, aynı zamanda muhalif ve alternatif bir iktidar ve yönetim modeli için kamu maliyesi teorisi ve pratiğini geliştirmeye davet etmektedir. Foucault 'nasıl hükmederim?', ya da 'katı kuralların denetimi altında nasıl en az maliyetle yönetirim?', ya da 'tehlikeler içinde özgürlükle nasıl yönetirim?’ sorusuna bağlı bir kamu maliyesi teorisi ve pratiği yerine kamu maliyesinin düşün ve pratik alanını geleneksel olarak tanımlayan üç iktidar modelini -egemenlik, disiplin, devletin sınırlanması ve piyasacı bireysel özgürlük- aşacak bir düşünüme ve pratiğe giden yolu tarif etmektedir. Foucault'nun yönetimsellik tarihinden ve analitiğinden ilhamını alan eleştirel maliye teorisi bizi liberalizmin uzun tarihine kayitlı iktisadi ve mali teorileri ve sistemleri iktidar yapıları içinde incelemeye ve alternatifi düşünmeye ve geliştirmeye yöneltmektedir.

\section{Kaynakça}

Backhouse, Roger E. (2008), "Keynesçi Devrim", Backhouse, Roger E. ve Bradley W. Bateman (Der.), Keynes (Ankara: Dost): 28-45 (Çev. Müfit Günay).

Bauman, Zygmunt (2017), Akışkan Modernite (İstanbul: Can Yayınları) (Çev. Sinan Okan Çavuş).

Bénicourt, Emmanuelle ve Bernard Guerrien (2017), Neoklasik iktisat Teorisi: Mikroekonomi, Makroekonomi ve Oyun Teorisi (İstanbul: İletişim) (Çev. Mustafa Dönmez, Hüseyin Şahin ve Ertuğrul Tokdemir). 
Boratav, Korkut (1983), Iktisat Politikaları ve Bölüşüm Sorunları, iktisat Yazıları 1969-1981 (İstanbul: Belge).

Campbell, Al vd. (2018), "The Unreal Basis of Neoclassical Economics", American Review of Political Economy, http://www.arpejournal.com/archived-issues/volume-13-issue-1-papers-andproceedings-of-the-2018-icape-conference/the-unrealistic-basis-of-neoclassicaleconomics/ (15.02.2019).

Clarke, Simon (1991), Marx, Marginalism \& Modern Sociology: From Adam Smith to Max Weber (London: Macmillan).

Dome, Takuo (2004), The Political Economy of Public Finance in Britain, 1767-1873 (London: Routledge).

Foucault, Michel (1972), The Archaeology of Knowledge and the Discourse on Language (New York: Pantheon Books).

Foucault, Michel (2002), The Order of Things (London/New York: Routledge).

Foucault, Michel (2006), Deliliğin Tarihi (Ankara: İmge) (Çev. Mehmet Ali Kılıçbay).

Foucault, Michel (2010), The Government of Self and Others (New York: Palgrave Macmillan) (Çev. Graham Burchell).

Foucault, Michel (2011), "Felsefe ve Psikoloji", Keskin, Ferda (Yay. Haz.), Felsefesi Sahnesi (İstanbul: Ayrıntı): 19-30 (Çev. Işık Ergüden).

Foucault, Michel (2013), Güvenlik, Toprak, Nüfus (İstanbul: İstanbul Bilgi Üniversitesi Yayınları) (Çev. Ferhat Taylan).

Foucault, Michel (2015), Biyopolitikanın Doğuşu (İstanbul: İstanbul Bilgi Üniversitesi Yayınları) (Çev. Alican Tayla).

Foucault, Michel (2019a), Özne ve İktidar, Keskin, Ferda (Yay. Haz.), (İstanbul: Ayrıntı) (Çev. Işık Ergüden ve Osman Akınhay).

Foucault, Michel (2019b), “Normun Toplumsal Yayılımı”, Keskin, Ferda (Yay. Haz.), Iktidarın Gözü (İstanbul: Ayrıntı): 79-84 (Çev. Işık Ergüden ve Osman Akınhay).

Foucault, Michel (2019c), "Göz Kamaştırıcı Hayvan: İktidar”, Keskin, Ferda (Yay. Haz.), Iktidarın Gözü (İstanbul: Ayrıntı): 151-166 (Çev. Işık Ergüden ve Osman Akınhay).

Foucault, Michel (2019d), "iktidar ve Bilgi", Keskin, Ferda (Yay. Haz.), Iktidarın Gözü (İstanbul: Ayrıntı): 167-184 (Çev. Işık Ergüden ve Osman Akınhay).

Foucault, Michel (2019e), “iktidarın Gözü”, Keskin, Ferda (Yay. Haz.), Iktidarın Gözü (İstanbul: Ayrıntı): 87-107 (Çev. Işık Ergüden ve Osman Akınhay).

Foucault, Michel (2019f), "Disiplinci Toplumda Krizde”, Keskin, Ferda (Yay. Haz.), Iktidarın Gözü (İstanbul: Ayrıntı): 245-247 (Çev. Işık Ergüden ve Osman Akınhay).

Foucault, Michel (2019g), Penal Theories and Institutions, Lectures at the Collège de France, 19711972 (Cham: Palgrave Macmillan) (Çev. Graham Burchell)

Foucault, Michel (2019h), “Michel Foucault: Filozofun Cevapları”, Keskin, Ferda (Yay. Haz.), Iktidarın Gözü (İstanbul: Ayrıntı): 64-78 (Çev. Işık Ergüden ve Osman Akınhay).

Frey, Bruno, Silke Humbert ve Firedrich Schneider (2009), "What is Economics? - Attitudes and Views of German Economists", Institute for Empirical Research in Economics University of Zurich Working Paper Series, No. 451.

Gulbenkian Komisyonu (2003), Sosyal Bilimleri Açın: Sosyal Bilimlerin Yeniden Yapılanması Üzerine Rapor (İstanbul: Metis) (Çev. Şirin Tekeli). 
Gürkan, Ceyhun (2016), "The Critique of Classical Political Economy in Foucault's Analytics of Power and Government", Felsefe ve Sosyal Bilimler Dergisi, 22: 99-118.

Hirschman, Albert O. (2008), Tutkular ve Çıkarlar: Kapitalizm Zaferini Ilan Etmeden Önce Nasıl Savunuluyordu? (İstanbul: Metis) (Çev. Barış Cezar).

Hume, David (1970a), "Of Taxes", Rotwein, Eugene (Der), Writings on Economics (Madison: The University of Wisconsin Press): 83-89.

Hume, David (1970b), "Of Public Credit", Rotwein, Eugene (Der), Writings on Economics (Madison: The University of Wisconsin Press): 90-107.

Hunt, Emery K. ve Mark Lautzenheiser (2016), İktisadi Düşünce Tarihi (Ankara: Phoenix) (Çev. Vedat Ulvi Aslan).

Kayalp, Orhan (2004), The National Element in the Development of Fiscal Theory (London: Palgrave Macmillan).

Keynes, John M. (1924a), "The End of Laissez-Faire", https://www.panarchy.org/keynes/ laissezfaire.1926.html. (28.02.2019).

Keynes, John M. (1924b), "Alfred Marshall, 1842-1924”, The Economic Journal, 34 (135): 311-372.

Keynes, John M. (1964), The General Theory of Employment, Interest, and Money (New York: Harbinger).

Kurz, Heinz D. (2017), Iktisadi Düşünce Tarihi (Ankara: Heretik) (Çev. Hüsnü Bilir ve Ekin Değirmenci).

Laidler, David (2008), "Keynes ve Modern Makro-Ekonominin Doğuşu”, Backhouse, Roger E. ve Bradley W. Bateman (Der.), Keynes (Ankara: Dost): 46-63 (Çev. Müfit Günay).

Mattei, Clara E. (2017), "Austerity and Repressive Politics: Italian Economists in the Early Years of the Fascist Government", The European Journal of the History of Economic Thought, 24 (5): 998-1026.

Marx, Karl (2012), Kapital 1. Cilt (İstanbul: Yordam) (Çev. Mehmet Selik ve Nail Satlıgan).

Musgrave, Richard (1959), The Theory of Public Finance: A Study in Public Economy (New York: McGraw-Hill).

Musgrave, Richard A. (1985), "A Brief History of Fiscal Doctrine", Auerbach, Alan A. ve Martin Feldstein (Der.), Handbook of Public Economics Vol. 1 (New York: Elsevier): 1-59.

Musgrave, Richard A. ve Alan T. Peacock (1964), "Introduction", Musgrave, Richard A. ve Alan T. Peacock (Der.), Classics in the Theory of Public Finance (London: Macmillan): ix-xix.

Myrdal, Gunnar (1953), The Political Element in the Development of Economic Theory (London: Routledge \& Kegan Paul LTD).

O'Brien, Patrick (1975), The Classical Economists (Oxford: Oxford University Press).

Polanyi, Karl (2001), The Great Transformation: The Political and Economic Origins of Our Time (Massachusetts: Beacon Press).

Ricardo, David (1997), Ekonomi Politiğin ve Vergilendirmenin Illkeleri (ìstanbul: Belge) (Çev. Tayfun Ertan).

Schabas, Maragaret (2005), The Natural Origins of Economics (Chicago/London: The University of Chicago Press.

Smith, Adam (2006), Milletlerin Zenginliği (İstanbul: İş Bankası Kültür Yayınları) (Çev. Haldun Derin).

Steuart, James (1998), An Inquiry into the Principles of Political Oeconomy (London: Pickering\&Chatto). 
Stiegler, Bernard (2012), Politik Ekonominin Yeni Bir Eleştirisi lçcin (İstanbul: Monokl Yayınları) (Çev. Elyesa Koytak).

Swingewood, Alan (1998), Sosyolojik Düşüncenin Kısa Tarihi (Ankara: Bilim ve Sanat Yayınları) (Çev. Osman Akınhay).

Veblen, Thorstein (1900), "The Preconceptions of Economic Science", Quarterly Journal of Economics, 14: 240-69.

Vergara, Francisco (2006), Liberalizmin Felsefi Temelleri: Liberalizm ve Etik (Illetişim: İstanbul) (Çev. Bülent Arıbaş).

Wicksell, Knut (1958), "A New Principle of Just Taxation”, Musgrave, Richard A. ve Alan T. Peacock (Der), Classics in the Theory of Public Finance (London: Macmillan): 72-118.

Wolff, Resnick D. ve Stephen A. Resnick (2016), Çatışan Iktisadi Teoriler: Neoklasik, Keynesçi ve Markş̧ı (İstanbul: İletişim) (Çev. Can Evren).

Zuidhof, PW (2014), "Thinking like an Economist: The Neoliberal Politics of the Economics Textbook". Review of Social Economy, 72(2): 157-185. 